Prace Literackie LIX

Wrocław 2019

https://doi.org/10.19195/0079-4767.59.1

MARIAN PACHOLAK

ORCID: 0000-0002-5868-7197

Uniwersytet Wrocławski

\title{
Listy Jana Czeczota. Faktografia w manuskryptach ${ }^{*}$
}

Pani Zofii z Karpowiczów Brzozowskiej (1924-1999) za ocalony świat Impresji czombrowskich tekst ten dedykuję.

\section{Korespondencja, materiały związkowe i literackie do 1823 roku}

Jan Antoni Czeczot, filomata, poeta, etnograf i tumacz, najbliższy przyjaciel Adama Mickiewicza, urodził się w niespełna rok po trzecim, pełnym już rozbiorze Rzeczypospolitej Obojga Narodów, 24 czerwca 1796 roku, we wsi Maluszyce, w parafii worończańskiej, w powiecie nowogródzkim, nieopodal Rajcy, Płużyn i Miratycz, tak licznych tu dworków i znanej z okolicznych opowieści Świtezi; by wymienić tylko kilka, bardziej znaczących miejsc z wciąż mającej się poszerzać przed nim topografii historycznej i literackiej ${ }^{1}$.

* Artykuł jest rozwinięciem i dopełnieniem jednego z fragmentów mojej niedrukowanej rozprawy doktorskiej, przygotowanej pod opieką prof. dr. hab. Mariana Ursela i obronionej 18 grudnia 2018 roku na Wydziale Filologicznym Uniwersytetu Wrocławskiego, a zatytułowanej Lektury filomatów w świetle zwiazkowej korespondencji lat 1817-1823. Od indywidualnych i zawodowych zainteresowań po wybór narodowych powinności. Natomiast dedykacja oraz sam tekst to jedyny dziś możliwy sposób podziękowania tym wszystkim, którzy skazany na zagładę świat Mickiewiczowskiego Soplicowa zdołali dla nas ocalić, a do 1945 roku pozostali tak dzielni, aby na tej ojczystej ziemi również przeżyć; zob. Z. Brzozowska, Impresje czombrowskie, Bydgoszcz 1997; M. Karpowiczowa, Listy z Czombrowa (oprac. J. Puchalska), Gdynia 2002; oraz J. Puchalska, Dziedziczki Soplicowa, Warszawa 2014.

1 S. Pigoń, Czeczot Jan (1796-1847), Polski Stownik Biograficzny (= PSB), t. 4, Kraków 1938, s. 316; Kronika życia i twórczości Mickiewicza: lata 1798-1824 (red. S. Pigoń), oprac. M. Dernałowicz, K. Kostenicz, Z. Makowiecka, Warszawa 1957, passim; Czeczot Jan (1796-1847), [w:] Bibliografia literatury polskiej „,Nowy Korbut”, t. 7. Romantyzm, oprac. I. Śliwińska, S. Stupkiewicz, Warszawa 1968, s. 246-249; 3. Яцкевіч, Радавод Яна Чачота, „Беларусіка-Albaruthenica”10, 
Pochodził z niezamożnej, lecz dość szeroko rozgałęzionej miejscowej szlachty herbu Ostoja. Rodzicami jego byli rotmistrz nowogródzki Tadeusz, zarządca dóbr hrabiego Antoniego Tyzenhauza w Rzepichowie, i matka Klara z Haciskich. Pośród krewnych i liczniejszego rodzeństwa bliżej znany jest jedynie młodszy brat poety, Piotr Paweł, który otrzymał sakrament chrztu 17 czerwca 1806 roku w parafii nowomyskiej, wówczas to bowiem rodzice Czeczota przenieśli się w okolice Nowej Myszy i Baranowicz².

\subsection{Okres dzieciństwa i lata szkolne}

Na temat wczesnego dzieciństwa Jana Czeczota nie dochowały się żadne dokumenty, jedyne informacje można odnaleźć w jego późniejszych rękopiśmiennych utworach: imieninowych wierszach, uzupełnianych balladach czy filomackiej korespondencji. Na drobne wskazówki można natrafić również w zebranych przezeń po latach tomikach folklorystycznych Piosnki wieśniacze, drukowanych w Wilnie (1837-1846) pod tymże wspólnym tytułem.

Mysz, Rzepichowo, Baranowicze (około $60 \mathrm{~km}$ na południe od Nowogródka) były zatem miejscami, pośród których upłynęło dzieciństwo Jana z Myszy (jak nazywali go filomaci), miejscami, do których zachował sentyment. Miały też wyraźny ślad w jego młodzieńczej twórczości poetyckiej: balladach Myszanka czy Uznohy oraz w Trenach, będących ich równie interesującym późniejszym dopełnieniem literackim.

We wszystkich tych utworach przeważają tematy i refleksje społeczne (feudalne zależności), niezmącona wiara dziecka w powszechnie obowiązujące prawdy Boże, w cyklu wierszy zaś określonych mianem „trenów” (zwłaszcza I, III i IV) oprócz treści akcentujących myśli moralizatorskie autor przedstawił (zapewne autobiograficzną) sylwetkę młodzieńca usiłującego dotychczasowe poszukiwania opisywać i racjonalizować3.

Mińsk 1998, s. 5-11; [J.M. Rymkiewicz], Czeczot Jan, [w:] J.M. Rymkiewicz et al., Mickiewicz: encyklopedia, Warszawa 2001, s. 90-91.

${ }^{2}$ W Cesarstwie Rosyjskim obowiązywał kalendarz juliański, starego stylu (v.s. = veteris stili, pierwsza data), różniący się w XIX wieku od kalendarza gregoriańskiego, nowego stylu (,rzymski”, n.s. = novis stili) o 12 dni. Personalia Czeczota ustalił L. Podhorski-Okołów, Czeczot nieznany, „Lech” (Warszawa) 1937 z. 3-4; Jan z Myszy, „Kurier Warszawski” 1937 nr 313; przedruk [w:] idem, Realia Mickiewiczowskie, t. 1-2, Warszawa 1952-1955 (wyd. 2, Warszawa 1999, s. 65-71 i 72-79). Dokument metryki nie podaje daty dziennej narodzin, z zapisków współczesnych wiadomo jednak, że „wybrał sobie imię sam” (podobnie Adam Mickiewicz 24 grudnia), przychodząc na świat w dniu św. Jana Chrzciciela.

${ }^{3}$ Rękopisy tekstów poetyckich zachowały się w spuściźnie Czeczotowej muzy, Zofii Brochockiej z d. Malewskiej (1808-1875), młodszej siostry filomaty Franciszka. Zbiór odkrył w 1922 roku w rodzinie późniejszych właścicieli Witold Klinger. Manuskrypty składały się wówczas z pięciu małych tomików: trzy pierwsze obejmowały w większości poezje J. Czeczota (pierwszy w części drugiej A.E. Odyńca), przeważnie własnoręcznie przez niego pisane, tomik czwarty zawierał wiersze T. Zana, a piąty odpisy młodzieńczych utworów A. Mickiewicza. Klinger nazwał cały zbiór „małym archiwum filaretów” i wybierając kilka utworów, ogłosił artykuł $Z$ niedrukowanych 
Jako dziesięciolatek chłonął już sporo z otaczającego go świata, ojciec poety był przecież ekonomem, więc syn mógł nie tylko przyglądać się pracom w polu, lecz także przysłuchiwać się białoruskim (szerzej: rusińskim) śpiewom i przyśpiewkom. Być może też losy Czeczota z Mickiewiczem splatają się już właśnie wówczas, gdyż w latach 1806-1810 w Nowej Myszy miał dzierżawę wuj Adama, Wincenty Stypułkowski, żonaty z siostrą Mikołaja Mickiewicza Barbarą. W życiu chłopięcym Jana momentem przełomowym stał się jednak jego wyjazd do szkoły powiatowej ojców dominikanów w Nowogródku, co mogło nastąpić dopiero w 1808 roku $^{4}$.

Nowogródek za czasów Rzeczypospolitej szlacheckiej był stolicą województwa. Wówczas, jak można przeczytać we wstępie do pracy Ignacego Emanuela Lachnickiego (Statystyka Guberni Litewski-Grodzieńskiej, Wilno: druk. J. Zawadzki, 1817), był już tylko miastem stołecznym jednego z ośmiu powiatów guberni grodzieńskiej. Sam powiat nowogródzki w 1817 roku, jak zanotował dalej autor opracowania, liczył 18 parafii oraz 17 miast i miasteczek, między innymi: „Cyriń, Horodyszcze, Korelicze, Mir, Niehniewicze, Nowa Mysz, Połonka, Snów, Stara Mysz, Swojatycze, Turzec i Wsielub"5.

poezji więziennych Jana Czeczota („Tygodnik Ilustrowany” 1922, nr 22); z odpisów korzystał też Stanisław Stankiewicz w rozprawie Pierwiastki białoruskie w polskiej poezji romantycznej (Wilno 1936). Po ostatniej wojnie sprawę przypomnieli Juliusz Saloni w artykule Rękopisy ze spuścizny po Zofii Malewskiej („Pamiętnik Literacki” 1948) i Stanisław Świrko w rozprawie Nieznany kopiariusz poezji Mickiewicza (,Rocznik Towarzystwa Literackiego im. Adama Mickiewicza” 1966; w wersji poszerz.: „Przegląd Humanistyczny” 1968, nr 4). Następnie J. Saloni przypomniał zagadnienie w kolejnych referatach: Czy nieznane poezje Mickiewicza? („Sprawozdania Polskiej Akademii Umiejętności” 1948, nr 9; por. Mickiewicz nieznany (rozm. S.K.), „Kuźnica” 1948, nr 44; oraz Pieśniarz i śpiewaczka. Rzecz o Janie Czeczocie i Zofii Malewskiej („Prace Polonistyczne” 1960). Artykuły te, a zwłaszcza pierwszy z nich, wprowadziły sporo zamieszania do problematyki autorstwa poezji Czeczota. Autor wysunął bowiem tezę, że tylko tomik II (Piosnki Jasia śpiewane dla Zosi) „można uznać za bezsprzecznie Czeczota”, co w sposób nie mniej przekonujący podważył S. Świrko (Twórczość więzienna Jana Czeczota i jej związki z poezja Adama Mickiewicza, „Rocznik Towarzystwa Literackiego im. Adama Mickiewicza" 1974). Wskazane trzy manuskrypty liczyły ogółem 230 utworów J. Czeczota: tomik I zbierał 20 piosnek (przeróbek z pieśni ludowych) i kilka przekładów, t. II liczył ich 100, a t. III zawierał Śpiewki (21 tekstów), cykl utworów Obłąkany (17 trenów) i 7 trenów nienumerowanych, dalej: 10 erotyków, kolejny cykl piosnek i zbiór „wierszy rozmaitych".

4 S. Świrko, Ballady Jana Czeczota, Warszawa 1964 (praca doktorska, streszczenie: „Biuletyn Polonistyczny" 1964, z. 21); idem, Z kręgu filomackiego preromantyzmu, Warszawa 1972; oraz idem, Z Mickiewiczem pod rękę, czyli życie i twórczość Jana Czeczota, Warszawa 1989.

5 Pamiętnik Franciszka Mickiewicza (wyd. J. Kallenbach; słowo wstępne W. Mickiewicz), Lwów 1923, s. 66; podobnie opisuje Nowogródek Edward Pawłowicz (Nowogródek w XIX wie$k u$, Lwów 1902, s. 13). Analizując powyższe informacje, Jarosław M. Rymkiewicz (Kilka szczegótów, Kraków 1994, s. 38-39), zauważał: „Jeśli liczby ze Statystyki Lachnickiego przeliczymy w stosunku procentowym, to wyjdzie nam, że w roku 1816 katolików (wszystkich wyznań) było 29\%, Żydów i Tatarów zaś 71\%. [...] Nowogródek był więc, w czasach mickiewiczowskich, miasteczkiem Żydów i Tatarów. [...] 29\% polszczyzny, ależ skąd, mniej znacznie mniej, ledwie jakieś kilkanaście procent, bo wśród tych $29 \%$ katolików wszystkich wyznań była przecież nie znana 
Styl życia tutejszej społeczności był raczej ziemiański, ożywiający się towarzysko pośród obywatelskich dworów głównie w czasie karnawałów, niekiedy przyjeżdżał tu również teatr z Wilna (około 140 kilometrów) czy z bardziej odległej Warszawy. Jak zapisywał po latach filomata Ignacy Domeyko: „miasteczko Nowogródek — niewiele się różniło od wsi i zaścianków naszych”. O Janie Czeczocie pisał:

Niski [kolejne filomackie przezwisko], okrągłej twarzy, zarówno pobłażający dla wszystkich, jak srogi dla siebie i dla Adama, był prawdziwie uosobioną czułością i miłością bliźniego. Z otwartym sercem dla wszystkich, był też pospolicie weselszym od Adama, i garnął ku sobie i do Adama tych nawet, których zrazu wyższość i genialność Adama nie ośmielały zbliżać się do niego z całą poufałością. [...] od najrańszych lat znali dobrze lud nasz litewski, polubili jego pieśni, przejęli się jego duchem i poezyą [...]. Przypatrywali się kiermaszom, targom i odpustom, bywali na weselach chłopskich, dożynkach i pogrzebach ${ }^{6}$.

Nowogródek był ważnym centrum edukacyjnym. Mieściła się tu jedna z ośmiu szkół powiatowych (nie licząc gimnazjum) guberni grodzieńskiej — szkoła średnia prowadzona przez ojców dominikanów, której system nauczania jest dziś dość dobrze znany dzięki raportowi hrabiego Adama Chreptowicza z 23-25 maja 1811 roku $^{7}$. W wielu spostrzeżeniach wizytator odnotował też nazwiska najpilniejszych uczniów. Byli nimi: „z klasy 3-ciej — Adam Mickiewicz, Konstanty Pilecki, Jan Czeczott (sic!), Dionizy Tomaszewski”; w tym roku szkolnym zatem Czeczot oraz repetujący (co było sprawą w zasadzie powszechną) Mickiewicz byli w jednej klasie i była to klasa III; samo wyróżnienie powtórzono w Kalendarzyku Politycznym... na rok 1812 (Wilno: druk. J. Zawadzki, 1811, s. 109).

nam, ale z pewnością duża liczba Białorusinów oraz Rosjan. [...] Mickiewicz [a zatem i Czeczot] mógłby zostać (w ostatniej chwili powstrzymam się przed napisaniem: powinien był zostać) białoruskim albo żydowskim poetą. Ale zostanie poetą Polaków. Stan wyjątkowy, stan oblężenia pewnie sprzyja językowi. Słyszy się wtedy, co to jest za język. Jaki on jest niebywały". Jak każda ciekawa refleksja historycznoliteracka także ta prowokuje kolejne pytanie: a może to siła polskiego dworu, znaczenie polskiego ziemiaństwa, były czynnikiem tak decydującym, że dla wszystkich tych grup narodowych właśnie język polski stał się na lata całe tym najbardziej poważanym, najbardziej atrakcyjnym, także w codziennej tutejszej mowie.

6 [I. Domeyko], O młodości Mickiewicza. List Ignacego Domeyki do Bohdana Zaleskiego z r. 1869, „Przegląd Lwowski” 4, 1872 (przedr. Księga pamiątkowa na uczczenie setnej rocznicy urodzin Adama Mickiewicza (1798-1898), t. 1, Warszawa (1898), s. 145-155; oraz Filareci i filomaci. List Ignacego Domejki (do Bronisława Zaleskiego; powst. 1870), „Rocznik Towarzystwa Historyczno-Literackiego w Paryżu" 1870-1872; w skróceniu H. Mościcki, Promieniści, filomaci, filareci (wyd. 3), Warszawa 1928; całość w: idem, Z filareckiego świata. Zbiór wspomnień z lat 1816-1824, Warszawa 1924, s. 73-105.

${ }^{7}$ I. Kadulska, O Szkole Powiatowej Nowogródzkiej XX. Dominikanów (omówienie Raportu wizytatora szkoły), „Studia Bałtyckie. Polonistyka” 1, 1998; eadem, W nowogródzkiej szkole. Rok 1811, [w:] Adam Mickiewicz i kultura światowa: materiały z międzynarodowej konferencji Grodno-Nowogródek, 12-17 maja 1997 r. w pięciu księgach, t. 1, red. S. Makowski, E. Szymanis, Warszawa 1999, s. 19-27; Z. Jędrychowski, ,Hamlet” w Nowogródku (1817), „Notatnik Teatralny” 2004, nr 35. 
W szkole nowogródzkiej zarówno Czeczot, jak i Mickiewicz uczyli się dobrze, a to nakładało na nich obowiązki, zwłaszcza w samorządzie uczniowskim, w dziale sądownictwa. Ostatni z nich przypominał sobie po latach:

W szkołach mieliśmy własne sądy i [...] używały takiej reputacji, że Żydzi w sprawach ze studentami na ich decyzji zupełnie polegali. Na prezydenta [sądu koleżeńskiego] najczęściej wybierany był Jan Czeczot albo Adam Wolski. Ja zawsze intrygowałem za Czeczotem.

Być może zatem sądom uczniowskim i szkolnej „praktyce adwokackiej” zawdzięczał współtowarzysz Mickiewicza trwalsze zainteresowanie procedurą prawniczą i przyszły wybór zawodu rejenta (notariusza). Jednak to wydarzenia roku 1812 dla Nowogródka i szkoły dominikanów, a zwłaszcza dla młodych jej wychowanków, były wydarzeniem na swój sposób pokoleniowym; do sygnaturki nazwiska dodadzą przecież za lat kilka drugie imię, Napoleona, cesarza Francuzów ${ }^{8}$.

W zamykającej edukację klasie VI oprócz obowiązków ,piątklasów słania woźnym pod pałki" (to filomackie jamby Mickiewicza) do głosu u obu przyjaciół doszły zainteresowania „godnej dla serca swego” płcią piękną, gdy „lube dziewczęta", zwłaszcza te modlące się w kościele (czyżby pokłosie lektury Petrarki?), stawały się ,i męczarnią, i słodkością” wszelką” (to wyjątki Trenu XIII).

Ostatni rok pobytu Czeczota w kolegium dominikańskim kończy okres jego lat pogodnych i beztroskich. Dziewiętnastoletni młodzieniec marzy o studiach uniwersyteckich, wiedząc, że z powodu niedostatku rodziców musi liczyć jedynie na własne siły. Zapewne więc $\mathrm{w}$ związku $\mathrm{z}$ brakiem środków materialnych Czeczot i Mickiewicz wybrali oferujący korzystne stypendium wydział medyczny, jednak wniosek, prawdopodobnie ze względu na stan ich zdrowia, nie został uwzględniony9.

Decyzja o studiach została jednak podjęta: po czerwcowym publicznym egzaminie i otrzymaniu stosownego świadectwa obaj przyjaciele z początkiem

${ }^{8}$ Notatki z rozmów z Adamem Mickiewiczem [...], spisane 15 maja 1846 r. przez E. Januszkiewicza, [w:] Żywot Adama Mickiewicza [...] (opowiedział W. Mickiewicz), t. 1, Poznań 1929, s. 13; Pamiętnik Franciszka Mickiewicza ..., s. 56. Kalendarzyk Polityczny... na rok 1811 (Wilno: druk. J. Zawadzki, 1810, s. 112) informował, że w szkole nowogródzkiej, jako ,uczniowie celujący" zostali zapisani z klasy II Czeczot, Kolesiński, Pilecki, a z klasy III — Mokłok, Wierzbowski i Mickiewicz. Adam i jego starszy brat Franciszek zostali wyróżnieni drukiem już w klasie I ( $\mathrm{Ka}$ lendarzyk Polityczny... na rok 1809, Wilno: druk. J. Zawadzki, 1808, s. nlb.); warto dodać, że wśród uczniów celujących podano tam też Nikodema Kiersnowskiego, Feliksa Tuhanowskiego i Augustyna Wereszczakę (syn Stefana, brat Antoniego, którego synowie uczyli się w Mińsku i kolegowali z Zanem); z kolei pośród ,studentów” gimnazjum wileńskiego z klasy I wymieniono między innymi Józefa Śniadeckiego i Franciszka Malewskiego. Rok później (Kalendarzyk Polityczny... na rok 1810, s. 102, 109) wyróżnienie ponownie otrzymał Malewski i Śniadecki, w gimnazjum zaś w guberni mińskiej wspomniany „Tomasz Zań (sic!) i Józef Wereszczaka” (syn Antoniego).

${ }^{9}$ Fragmenty Trenu XVI i innych wierszy Czeczota cyt. za: S. Świrko, Z Mickiewiczem pod rękę..., s. 22-30; A. Mickiewicz, Janowe (Czerwca 24 n. s. 1819 r. w Górach), [w:] A. Mickiewicz, Wiersze: 1817-1824, t. 1, oprac. C. Zgorzelski (wyd. pomnikowe), Wrocław 1971, s. 132-139. O planowanym stypendium w wydziale medycznym Uniwersytetu Wileńskiego zob. L. Podhorski-Okołów, Szczegóty z młodości Mickiewicza, [w:] idem, Realia Mickiewiczowskie, s. 43. 
września 1815 roku udali się do tętniącego pełnią życia towarzyskiego, naukowego i kulturalnego Wilna.

\subsection{Wilno i Towarzystwo Filomatów}

U progu drugiej dekady XIX wieku w dawnej stolicy Wielkiego Księstwa Litewskiego rozwija się $\mathrm{w}$ nieznanym dotychczas stopniu i natężeniu warstwa społeczna, inteligencja, którą tworzy tu — zwłaszcza od czasów odnowienia Szkoły Głównej jako Imperatorskiego Uniwersytetu Wileńskiego (1803) - coraz liczniejsza rzesza studentów. W większości była to drobna lub tylko średniozamożna szlachta, rekrutująca się głównie z guberni wileńskiej, grodzieńskiej lub mińskiej, z głęboko motywującym postanowieniem, aby do rodzinnego herbu dodać patent potwierdzający wykształcenie lub przynajmniej tytuł „kandydata nauk”10.

Stołeczne miasto wraz ze swoim intelektualnym zapleczem pozostawało więc nadal kulturowym tyglem byłych ziem wschodnich Rzeczypospolitej: od Kowna i Połocka na północy, po Krzemieniec i Kamieniec Podolski na południu. Teraz w ośmiu guberniach i tyluż uniwersyteckich okręgach szkolnych, zaś dawna Wszechnica Batorowa, nadal z polskim językiem wykładowym, była jedną z najbardziej licznych i znaczących europejskich uczelni, choć tylko jedną z sześciu wydziałów naukowych imperium rosyjskiego, podlegających Głównemu Zarządowi Szkół w Petersburgu.

Adam Mickiewicz złożył we wrześniu 1815 roku konkursowy egzamin wstępny do stanu nauczycielskiego, rozpoczynając od poprzedzającego roku przygotowawczego na wydziale matematyczno-fizycznym trzyletnie studia nad literaturą. Natomiast Jan Czeczot z powodu niewystarczających środków do życia musiał odłożyć marzenia o studiach prawniczych. W roku akademickim 1816/1817 i w kolejnych był jedynie (jeśli „obowiązek na to pozwalał”) wolnym słuchaczem wydziału nauk moralnych i politycznych. Wybierając studia nad Statutem litewskim i prawem krajowym, starał się je łączyć z obowiązkami sekretarza i praktyką sądową, dającą elementarne środki utrzymania. W 1818 roku uzyskał miejsce pisarza w Prokuratorii Masy Radziwiłłowskiej, komisji powstałej po śmierci ostatniego potomka z linii nieświeskiej, księcia Dominika Radziwiłła; zatrudniony był tam również jego przyszły kolega Onufry Pietraszkiewicz. Pewnym urozmaiceniem żmudnej pracy, jak sam określał „piszczyka”, stały się jego wyjazdy na tak zwane kontrakty, podczas których zobowiązany był załatwiać wszystkie zlecane mu sprawy finansowe. W tym charakterze przebywał w Miń-

${ }^{10}$ G. z Güntherów Puzynina, $W$ Wilnie $i$ w dworach litewskich. Pamiętnik z lat 1815-1843 (powst. przed 1867), wyd. A. Czartkowski i H. Mościcki, Wilno 1928 (reprint: Kraków 1988). Zob. także J. Bieliński, Uniwersytet Wileński 1579-1831, t. 1-3, Kraków 1899-1900; L. Janowski, W promieniach Wilna i Krzemieńca, Wilno 1923; D. Beauvois, Wilno: polska stolica kulturalna zaboru rosyjskiego 1803-1832, przeł. I. Kania, Wrocław 2010; A. Witkowska, Rówieśnicy Mickiewicza: życiorys jednego pokolenia, Warszawa 1962. 
sku i Nowogródku, a na przełomie lat 1821/1822 w stolicy Królestwa Polskiego, Warszawie.

Jesienią 1817 roku, z powodu rozluźnienia stosunków koleżeńskich, Czeczot nie należał zatem do członków-założycieli wileńskiego Towarzystwa Filomatów (Adam Mickiewicz, Onufry Pietraszkiewicz, Józef Jeżowski i Tomasz Zan), choć później stał się jednym z najwybitniejszych jego przedstawicieli. Do końca tego roku przyjęto tam jeszcze: Józefa Kowalewskiego z wydziału literatury, Franciszka Malewskiego, syna rektora i przyszłego prawnika, oraz Zygmunta Nowickiego z wydziału nauk fizycznych, w następnym zaś tylko dwóch: Jana Czeczota i Teodora Łozińskiego ${ }^{11}$.

W 1819 roku Towarzystwo zasiliło sześciu członków: późniejszy proboszcz Dionizy Chlewiński z wydziału nauk moralnych i politycznych, Dominik Chodźko z wydziału literatury, Ignacy Domeyko i Jan Sobolewski, obaj z wydziału fizyczno-matematycznego, oraz Kazimierz Piasecki i Michał Rukiewicz z wydziału prawa. W 1820 roku przyjęto tylko jednego - Wincentego Budrewicza z wydziału matematycznego, a w 1822 roku dołączył tu jeszcze student wydziału prawa Stanisław Kozakiewicz.

Jako kandydat do Towarzystwa Filomatów Jan Czeczot został zgłoszony przez Józefa Jeżowskiego 2 czerwca 1818 roku, a dwa tygodnie później, 16 czerwca, przyjęto go na członka proponowanego. Następnie, razem z Teodorem Łozińskim 29 czerwca zostali wprowadzeni na posiedzenie nadzwyczajne jako członkowie korespondenci i jednomyślnie przyjęci na członków czynnych: Jan Czeczot 25 listopada; uroczyste wprowadzenie odbyło się 12 stycznia 1819 roku.

W gronie filomatów Czeczot dość rzadko zabierał głos w sprawach organizacyjnych czy programowych, pośród pięciu swoich prac związkowych przygotował jednak tak istotne dla dalszych działań Towarzystwa, poparte rozleglejszą lekturą, Uwagi nad instrukcją krajowa szkolna. Powołany wówczas pod kierunkiem Malewskiego Komitet Statystyczny potajemnie, w nakładzie 200 egzempla-

${ }^{11}$ Jedyną jawną formą organizacyjną filomatów było Zgromadzenie Przyjaciół Pożytecznej Zabawy, czyli Towarzystwo Promienistych (pod kierownictwem T. Zana). Jego działalność zaniepokoiła jednak tak władze uniwersyteckie, że rektor Szymon Malewski nakazał rozwiązanie organizacji. Gdy jesienią 1820 roku praca filomatów wróciła do form tajnych, zorganizowano Zgromadzenie Filaretów, które w ciągu dwóch lat objęło swoją aktywnością około 200 studentów reprezentujących siedem związków (gron). Ponieważ spośród pierwszych organizatorów Towarzystwa kilku najważniejszych po ukończeniu nauki musiało opuścić Wilno (Mickiewicz, Malewski, Pietraszkiewicz), w październiku 1821 roku filomaci powzięli uchwałę o zawieszeniu działalności, rolę kierowniczą powierzając wcześniej utworzonemu Związkowi Przyjaciół, który przybrał nazwę Związku Filadelfistów. Na początku 1822 roku T. Zan poinformował rektora o istnieniu Towarzystwa Filaretów. W odpowiedzi otrzymał polecenie, aby papiery filareckie oddać, a organizację rozwiązać. W końcu kwietnia 1822 roku archiwum filareckie zostało spalone, lecz po paru tygodniach Zan przystąpił do reorganizacji Towarzystwa i działalność filaretów wznowiono. Zob. S. Pietraszkiewiczówna, Dzieje filomatów w zarysie, „Przegląd Powszechny” 1909-1911 (wyd. osobne: Kraków 1912); biogramy podają kolejne tomy PSB (Kraków 1935-), literaturę przedmiotu zestawia Bibliografia literatury polskiej ,,Nowy Korbut”, t. 7, s. 68. 
rzy, wydrukował broszurę Opis jeograficzny, czyli instrukcja do układania opisu parafii (Wilno 1821).

Czeczot nie tylko w tym referacie dał się poznać jako „miłośnik ksiąg”, albowiem musiał należeć do osób wyjątkowo pracowitych, skoro rząd Towarzystwa Filomatów po wyjeździe Pietraszkiewicza do Warszawy 13 października 1820 roku wyznaczył właśnie jego do spisania i uporządkowania dość sporej, powstałej z darów i zakupów, związkowej biblioteki; od lipca 1819 do kwietnia 1821 roku trafiło tam (z czasopismami i rękopisami) ponad 114 tytułów. Czeczot, dysponując skromnymi środkami finansowymi, sprezentował 14 dzieł, w tym jedno rękopiśmienne, zaś działającemu w Związku Przyjaciół Komitetowi ofiarował tablicę statystyczną powiatu wileńskiego ${ }^{12}$.

Będąc sekretarzem Towarzystwa Filomatów, działał głównie w Związku Przyjaciół, (delegowany 7 kwietnia 1819 roku), dwukrotnie pełnił funkcję prezydenta. Najczynniejszą działalność rozpoczął jednak w Towarzystwie Filaretów: był dwukrotnie prezesem i przewodnikiem Związku Błękitnego (grono literackie), a po jego zawieszeniu potrafił skupić dookoła siebie młodzież o ambicjach (i zdolnościach) literackich. W kwietniu 1823 roku z działań tych wyłonił się klub poetycki Kastala z projektem własnego tomiku (,almanaka”) i okolicznościowego kalendarza.

Dla wielu filaretów był mentorem szerzącym, na wzór filozofów starogreckich, związkowy kult koleżeństwa i przyjaźni. Przede wszystkim jednak dał się poznać jako niestrudzony piosenkarz Towarzystwa („Janko-lutnista”) i żadne obchody imieninowe, konkursy czy majówki nie odbywały się bez jego ,jambów" i śpiewek. Specjalnością Czeczota były bowiem polskie i białoruskie piosnki, składane okolicznościowo na wzór „zasłyszanych” pieśni ludowych. Niektóre z nich (Sztoż my waszeci skażem...) weszły na stałe do repertuaru filomackich spotkań.

W czasie pobytu w Wilnie, co nie pozostało bez wpływu na jego twórczość literacką, zakochał się w (przedstawionej mu przez Zana) Zofii Malewskiej, „zawsze najdroższej Zosi”, młodszej siostrze Franciszka, której jako wybrance serca ofiarował później trzy wspomniane rękopiśmienne zbiorki swoich pieśni.

Czeczot próbował swych sił literackich, podejmując się także twórczości wyższego rzędu. W związkowym archiwum zachowało się kilkanaście tytułów anakreontyków, dum, ód, „śpiewów”, w stylu Kniaźnina, Niemcewicza, to znów

12 Archiwum filomatów powstało i ocalało dzięki staraniom O. Pietraszkiewicza, który jako bibliotekarz Towarzystwa zbierał, a później potrafił doskonale ukryć wszystkie posiadane dokumenty, po powrocie z tułaczki zajmował się ich uporządkowaniem - cz. 1. Korespondencja 1815-1823, t. 1-5 (wyd. J. Czubek), Kraków 1913; cz. 2. Materiały do historii Towarzystwa Filomatów, t. 1-2 (wyd. S. Szpotański i S. Pietraszkiewiczówna), Kraków 1920-1921; t. 3, wyd. S. Pietraszkiewiczówna, Kraków 1934; oraz cz. 3. Poezja filomatów, t. 1-2 (wyd. J. Czubek), Kraków 1922; dalej: Korespondencja, Materiały, Poezja. Oprócz „wiadomości naukowych” zachowało się tam łącznie pięć prac związkowych J. Czeczota: Materiały..., t. 2, s. 273, 396, oraz w t. 3, s. 365, 367, 485; zob. też A. Witkowska, Wybór pism filomatów. Konspiracje studenckie w Wilnie 1817-1823, Wrocław 1959, s. 471-476. 


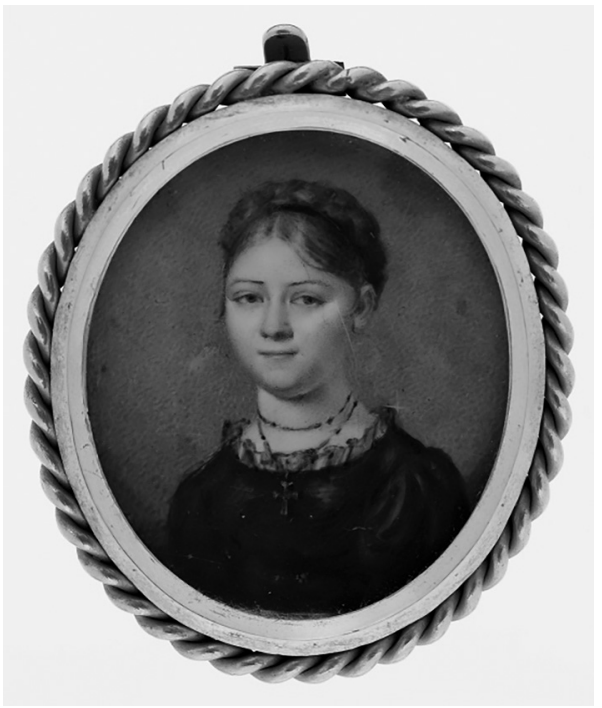

Il. 1. Zofia Malewska. „Muse des Philomates” (miniature ovale non signée, diam. $5 \times 4.5 \mathrm{~cm}$ ). Biblioteka Polska w Paryżu, nr inwent.: THL/BPP.Rys.Min.9.

Digitalizacja: projekt PAUart, domena publiczna.

Pindara czy Osjana; jest nawet libretto operetki wieków średnich Małgorzata z Zębocina, której poetycki pogłos odnaleźć można w Liliach Mickiewicza. Niestety, znaczna część tych anakreontyków i śpiewów nie dotrwała do naszych czasów ${ }^{13}$.

Napisał też około 10 ballad, ocalało zaledwie kilka. Niektóre z nich, pośród prób literackich kolegów w różnorodnych wariantach (rzecz nowatorska), powiązane są z Mickiewiczowskimi wierszami. Jak zauważał przed laty Józef Ujejski: „Tematy tak się pokrywają wśród poetów-filomatów, jakby były konkursowe. Świtezie są aż trzy, Bekiesza i Ariona dublują Zan i Czeczot, Twardowskiego znów Zan i Mickiewicz"14.

${ }^{13} \mathrm{~W}$ związkowym archiwum zachowało się ponad 20 utworów poetyckich Czeczota i około 30 okolicznościowych wierszy lub ich fragmentów (w tym 6 znanych z zawartości „,małego archiwum filaretów"; całość ogłosił J. Czubek, Poezja filomatów, t. 1-2, passim; zob. J. Saloni, Rękopisy..., s. 494. Przedstawił też przynajmniej 4 związkowe recenzje, między innymi przekłady A. Mickiewicza Dziewicy Orleańskiej. Pieśń V (Poezja filomatów, t. 1, s. 348) oraz Sielanka: Kurhanek Maryli, przeł. z litewskiego (sic!) A. Mickiewicza (tekst: J. Tretiak, Adam Mickiewicz w świetle nowych źródet: 1815-1821, Kraków 1917, s. 313-316).

14 Balladami filomaty zainteresowano się dopiero po odnalezieniu tak zwanego Raptularza Czeczota, który po śmierci autora przeszedł na własność Adolfa Kobylińskiego, ten przekazał manuskrypt w 1888 roku za pośrednictwem E. Pawłowicza do ZN im. Ossolińskich we Lwowie. Z Czeczotowych ballad znalazły się tam między innymi Bekiesz, Zamek nowogródzki, Szczupak kołdyczewski oraz Uznohy, Myszanka i Świtéz; na tekstach rękopisów (pisanych nieznaną ręką) widoczne są poprawki autora. Pierwszą informację o zbiorze podał Józef H. Rychter w dwóch artykułach (Świteź i Świteź: Mickiewicza i Czeczota, „Dziennik Polski” 1886, nr 295; Jan Cze- 
Do najbardziej udanych utworów Jana Czeczota z tego okresu należy, przedstawiona przez Mickiewicza 17 listopada 1818 roku w Wydziale I Towarzystwa Filomatów, Duma nad mogitami Francuzów, elegia o sporym stopniu obrazowości, będącym punktem wyjścia do żarliwych autorefleksji nad losem Rzeczypospolitej (republikańskiego Rzymu) i przepełniona nienawiścią do carskiego despoty. Podobną siłą brzmieć będzie, o rok późniejszy, szeroko sławiący spartańskie cnoty i odwagę walki za ojczyznę poemat Tyrtej (Tyrteusz), „Czeczotowa oda do wolności”.

Poeta z Nowogródka doceniał twórczość przyjaciela (czemu niejednokrotnie dawał wyraz w korespondencji), Czeczot zaś bezinteresownie przepisywał jego utwory, przedstawiał na posiedzeniach filomackich, z czasem przeprowadzał nawet ich korekty. W gronie filomackim szczególne znaczenie miały jednak wspomniane uzdolnienia do pisania „dydaktycznych” wierszy okolicznościowych. Przykładowo na jednym ze spotkań, 31 grudnia 1818 roku, wygłosił swój wiersz Śpiew: Leszek i Goworek Adamowi Napoleonowi w dzień jego imienin przez siebie poświęcony, będący dopełnieniem spopularyzowanego przez Juliana Ursyna Niemcewicza w Śpiewach historycznych (Warszawa 1816), a na tutejszym gruncie przez profesora Leona Borowskiego (Leszek Biały i Goworek, śpiewak oryginalny, „Dziennik Wileński” 5, 1817, nr 29) popularnego i cenionego wówczas dialogu o przyjaźni ${ }^{15}$.

czot i jego nieznane poezje, „Ognisko Domowe” 1887, nr 97-101); o samym rękopisie wkrótce jednak zapomniano. Raptularz, bez edycji krytycznej tekstów, przywrócił nauce dopiero Czesław Zgorzelski (O tzw. ,Raptularzu” Czeczota, „Rocznik ZN. im. Ossolińskich” 4, 1953); idem, Nowa Sofiówka, „Roczniki Humanistyczne” 1954/1955). Wymienione ballady, powstałe najprawdopodobniej w 1819 roku (lub niewiele lat później), odznaczają się silnym związkiem z autentyczną, nie kostiumową przecież, twórczością ludową. Potwierdzają zainteresowania ludoznawcze Czeczota i to w czasach, gdy nie istniały jeszcze, jako samodzielne nauki, etnografia czy komparatystyka; teksty tych (programowych) ballad zakwalifikować można do funkcjonującej do dziś tak zwanej ballady z tezą. Interesujący jest również ich wpływ na twórczość Mickiewicza: „Pamiętać też należy — podnosił Juliusz Kleiner (Mickiewicz, t. 1. Dzieje Gustawa, Lwów 1934, s. 192) — że na r. 1820 przypada Świteź Tomasza Zana, a na r. 1819 Świteź Czeczota [...] oba te utwory mogły pobudzić Mickiewicza z chwilą, gdy ballady stały się głównym tematem jego twórczości. Czeczot potem przerobił swą Świteź i we wstępie sławił trzy wianki, jakie Świtezi splótł Adam" — zob. J. Ujejski, Ballady Tomasza Zana, [w:] Księga pamiatkowa celem uczczenia 350-ej rocznicy założenia Uniwersytetu Stefana Batorego w Wilnie, Wilno 1931, s. 339-398; S. Świrko, Z kręgu filomackiego preromantyzmu..., s. 125-195 („Raptularz Czeczota”).

15 Niestety żaden z tekstów Czeczota nie ukazał się drukiem. Na łamach „Dziennika Wileńskiego" debiutował T. Zan wierszem Do algebry (6, 1817, nr 35), w „Tygodniku Wileńskim” (3, 1817, nr 61) Pietraszkiewicz, ogłaszając sentymentalne liryki (Strumyk, fiołek i róża oraz Do...), a rok później Mickiewicz klasycystyczną Zima miejska (6, 1818, nr 125); zob. H. Czernianin, Przed debiutem Mickiewicza. Poezja w „Tygodniku Wileńskim” 1815-1822, [w:] Na przełomie Oświecenia i Romantyzmu: o sytuacji w literaturze polskiej lat 1793-1830, red. P. Żbikowski, Rzeszów 1999, s. 77-86; J. Kowal, Tradycja oświecenia stanisławowskiego na łamach „Dziennika Wileńskiego” z lat 1815-1830, „Prace Polonistyczne” 2016, s. 101-119. 
W roku 1819 i następnym filomaci w większości opuszczają Wilno. Rozpoczyna się okres żywej korespondencji, którą umożliwił Malewski, organizując tanią przesyłkę poczty za pośrednictwem kancelarii uniwersyteckiej; inna rzecz, że było o czym pisać i filomaci tych listownych rozmów zawsze oczekiwali.

Wakacje 1820 roku Czeczot, podobnie jak Pietraszkiewicz, związany obowiązkami w Masie Radziwiłłowskiej, spędził w Wilnie (Malewski w Szczorsach, Mickiewicz i Zan w Tuhanowiczach). Na urlop w rodzinne strony udał się dopiero 20 sierpnia, a w końcu tegoż miesiąca w towarzystwie braci Mickiewicza - na wycieczkę do Szczors.

W lipcu 1821 roku także przesiaduje w Wilnie, jako Janko Arystydes (tak nazywa go Malewski) odpisuje na listy, załatwia subskrypcję na wydane przez Józefa Jeżowskiego Ody Horacjusza (Ody celniejsze do użytku szkót objaśnione, t. 1-2, Wilno 1821-1823) i wiele innych koleżeńskich „spraw naglących”. Na wypoczynek do rodziców wybiera się dopiero w połowie sierpnia. Do Wilna powraca na początku września, przybywa tu również Mickiewicz, który otrzymał wprawdzie roczny urlop, lecz jego starania o paszport zagraniczny okazały się bezskuteczne.

W 1822 roku Uniwersytet Wileński żył już wykładami Joachima Lelewela, a w miejsce projektowanego periodyku „Hebe” Czeczot zajął się prenumeratą Poezji Mickiewicza. Koszty jednego egzemplarza (w trzech tomikach) wyceniono na 10 złotych, bilety subskrypcyjne w liczbie 500 sztuk (na tyle pierwotnie planowano nakład) rozprowadzano za pośrednictwem filomatów i filaretów.

Batorowa wszechnica miała wkrótce gościć księcia Adama Jerzego Czartoryskiego. Nikt zatem nie zwrócił specjalnej uwagi, że po tak zwanych studenckich incydentach Szymon Malewski musiał ustąpić z rektorstwa, na jego miejsce książę kurator mianował profesora Józefa Twardowskiego, a w połowie czerwca 1822 roku ukazał się tak oczekiwany przez filomatów pierwszy tomik Mickiewiczowskich Poezji dedykowanych czwórce najbliższych druhów: Czeczotowi, Zanowi, Jeżowskiemu i Malewskiemu.

W pierwszych dniach września Mickiewicz jest już w Kownie, natomiast Czeczot po powrocie do Wilna rozpoczyna korespondencję ponaglającą autora Ballad i romansów o kolejny manuskrypt wierszy. Po dokonanym w tajemnicy dodruku tomiku pierwszego (tysiąc egzemplarzy) jest już w pełnym tego słowa znaczeniu redaktorem i korektorem tomiku drugiego. Wymiana kilkudziesięciu listów, w obu kierunkach, przybliżająca tak wiele spraw dotyczących jego wyrobienia artystycznego trwać będzie niemal rok.

$\mathrm{Na}$ Wielkanoc 22 kwietnia 1823 roku, gdy Mickiewicz przyjechał do Wilna, Czeczot mógł z radością odebrać u Józefa Zawadzkiego drugi tomik, jednak do nowych obowiązków przybyły mu kolejne troski: o prenumeratę, kolportaż i zamykający całość planowanego wydania tomik trzeci. Chwilą wytchnienia był wyjazd 9 marca 1823 roku do Bolcienik, gdzie z wspólnie z Zanem zostali zaproszeni przez Wawrzyńca i Marylę Puttkamerów; niebawem znajomość ta przerodziła się w serdeczną przyjaźń. 
Poza wszystkim Czeczot kochał się bez pamięci (i szans na odwzajemnienie uczuć) w obdarzonej wyjątkową urodą i nieprzeciętnym talentem wokalnym Zosi Malewskiej; admiratorem młodziutkiej rektorówny był również Tomasz Zan, co nie przeszkadzało mu obdarowywać wierszami „niebieskiej Feli”, czyli panny Felicji Micewiczówny.

Wydawać się też mogło, że bez większych konsekwencji przejść może kolejny wileński epizod, jakim było pojawienie się 3 maja 1823 roku w tutejszym gimnazjum patriotycznego napisu: „Vivat Konstytucja 3 maja, jak słodkie wspomnienie dla nas rodaków". Nikt nie przeczuwał, że dla studentów i ich rodzin to błahe w gruncie rzeczy wydarzenie miało przynieść tak tragiczne konsekwencje.

\subsection{Przyjacielska korespondencja}

Wyjątkowym wydarzeniem w nauce polskiej tuż przed I wojną światową było opublikowanie przez Jana Czubka pierwszej części związkowego archiwum — Korespondencji filomatów; część drugą i trzecią (Materiaty... oraz Poezje...) drukowano już w niepodległej II Rzeczypospolitej. Dopiero wówczas stało się też możliwe spojrzenie na wileńskie Towarzystwo nie tylko przez, od dziesięcioleci przeważające, obrazy martyrologiczne III części Dziadów (Paryż 1832), powstałe niemal równolegle z opisami Joachima Lelewela (Nowosilcow w Wilnie, Warszawa 1831) i niemówiącymi zresztą pełnej prawdy o losie pozostałych nadal pod władzą caratu „spółwygnańców”16.

Archiwum filomatów przynosiło zapis zarówno trudów ich codziennej pracy, jak i świątecznej zabawy. Kreśliło sylwetki studentów, którzy bynajmniej nie byli ascetami, lecz przedstawiali się jako spragnieni radości życia członkowie republikańskiej wspólnoty przyjaciół, z górującym ponad wszystkie te młodzieńcze pragnienia hasłem pokolenia: „Ojczyzna, Nauka i Cnota”. Na czoło przywódców Towarzystwa wysunięto wtedy, zgodnie ze zweryfikowanym materiałem, Jeżowskiego, Malewskiego i Mickiewicza, pełniej widząc rolę i znaczenie przywódcze Zana; jeszcze inne miejsce, tuż obok poety z Nowogródka, znalazł Jan Czeczot.

Najobszerniejszy zespół epistolarnych rozmów jest dziełem Franciszka Malewskiego - 128 listów, następny Jana Czeczota — 96 oraz Adama Mickiewicza — 95 (można się domyślać, że najczęściej też odbierał listy), dalej: Józefa Jeżow-

${ }^{16}$ Archiwum filomatów, cz. 1. Korespondencja 1815-1823, t. 1-5, wyd. J. Czubek, Kraków 1913 (rec. J. Kleiner, „Pamiętnik Literacki” 1916). Zob. także J. Kallenbach, Adam Mickiewicz, t. 1-2, Lwów 1926 (wyd. 4); Z. Jabłońska-Erdmanowa, Oświecenie i romantyzm w stowarzyszeniach młodzieży wileńskiej na początku XIX w., Wilno 1931; Filomaci w Wilnie, oprac. M. Dunajówna, Wilno 1935. Fragmenty siedmiu listów Czeczota do M. Puttkamerowej ogłosił W. Mickiewicz w Żywot Adama Mickiewicza, t. 1, Poznań 1890 (Dodatek XVIII), trzy (we fragmentach) do F. Malewskiego w Korespondencja Adama Mickiewicza, t. 3, Paryż 1876 i t. 9. Dzieła Adama Mickiewi$c z a$, Paryż 1884. Związkową epistolografię zbierają też dwie późniejsze publikacje: Korespondencja filomatów (1817-1823), wybór M. Zielińska, Warszawa 1989; i Korespondencja filomatów: wybór, oprac. Z. Sudolski, Wrocław 1999. 
skiego - 78, Tomasza Zana - 75 i Onufrego Pietraszkiewicza - 57 listów; inni pozostawili zdecydowanie mniejszą liczbę korespondencji ${ }^{17}$.

W zachowanej Korespondencji z lat 1815-1823 Czeczot jest autorem 96 listów: 8 do Józefa Jeżowskiego (ten skierował doń 18), 1 do Stanisława Kozakiewicza (brak korespondencji zwrotnej), 7 do Maryli Puttkamerowej (odpowiedziała na 6) oraz 60 do Mickiewicza (poeta przesłał 43) i 20 do Pietraszkiewicza (odpowiedział na 24); daje to zatem zbiór 91 odpowiedzi wskazanych nadawców.

Z tychże 14 listów Czeczot napisał w 1819 roku, 21 w 1820 roku, 19 w 1821 roku, 14 w 1822 roku i aż 28 w 1823 roku. Zdecydowana większość korespondencji została wysłana z Wilna — 84 listy, 7 z Warszawy, 2 z Nowogródka i tylko po 1 ze Szczuczyna, Mińska i Białej; zarazem to kilka kolejnych miejsc jego topografii biograficznej, tym razem epistolarnej.

Z kolei listy do Jana Czeczota przesłali (to $68 \mathrm{z}$ ocalałych, bez odpowiedzi odbiorcy, oprócz 91 wskazanych powyżej): Antoni E. Odyniec - 10 listów, Ferdynand Nowicki - 9, Michał Kulesza - 8, Walerian Krasiński, Franciszek Mickiewicz, Kazimierz Piasecki i Wawrzyniec Puttkamer - po 6, Michał Rukiewicz - 5, Franciszek Malewski, Wincenty Pełczyński i Tomasz Zan — po 2 oraz Lucjan Eysymont, Jerzy Frąckiewicz, Stanisław Golicki, Józef Kwieciński, Marian Piasecki i Jan Sobolewski — po 1. Tym razem daje to łącznie zbiór 96 listów autorstwa Jana Czeczota do 5 osób oraz 159 listów przesłanych do niego przez 21 nadawców.

Każdy z nich jest znakomitym źródłem dokumentarnym w wielokierunkowych eksploracjach i ustaleniach historycznoliterackich. Chociażby w zakresie lektur filomaci podkreślali wartość samokształcenia w poznawaniu „narodowych dziejów” (kult „,polskiej mowy”), zalety upowszechniania wzorów postawy obywatelskiej (literatura starożytna i tradycjonalizm), doceniając najnowszą literaturę niemiecką, francuską i angielską (stąd tak częste podejmowanie przez nich translatorskiego trudu), z czcią i powagą natomiast omawiano poezje Mickiewicza (ludowość i balladomania) ${ }^{18}$.

${ }^{17}$ Korespondencja Czeczota z Mickiewiczem tworzy największy, oprócz korespondencji Mickiewicza z Malewskim, blok listów z okresu filomackiego. Jest nie tylko świadectwem spraw codziennych i przysług oddawanych przyjacielowi (nawet zaangażowania w jego romans z Marylą), przede wszystkim oświetla bowiem historię powstania II i IV części Dziadów; zob. C. Zgorzelski, Materiały do dziejów wileńskiej edycji „Poezyi” Mickiewicza, „Pamiętnik Literacki” 1966, z. 4; S. Pigoń, Formowanie „Dziadów” części drugiej: rekonstrukcja genetyczna, Warszawa 1967; S. Świrko, Jan Czeczot jako redaktor i korektor drugiego tomu Poezji Mickiewicza, „Rocznik Towarzystwa Literackiego im. Adama Mickiewicza” 7, 1972.

18 Zob. M. Strzyżewski, Listy „prawie recenzenckie” Mickiewicza, [w:] Mickiewicz niedoczytany...: korespondencja poety w perspektywie wspótczesnej, red. E. Hoffmann-Piotrowska, Warszawa 2014, s. 185-190; D. Zawadzka, Czytanie i pisanie w życiu filomatów, [w:] Wilno i Kresy Pótnocno-Wschodnie, t. 4. Literatura, red. E. Felisiak, Białystok 1996, s. 23-49; M. Cwenk, Czeczot (jeszcze) nieznany. Uzupetnienie „Poezji filomatów” J. Czubka, [w:] W cieniu Mickiewicza, red. J. Lyszczyna, Katowice 2006, s. 212-223; M. Frączek, Jan Czeczot - prekursor białoruskiej folklorysty, [w:] Romantycy na krańcach świata: podróże egzotyczne i peregrynacje wewnętrzne, red. E. Modzelewska, Kraków 2015, s. 133-140. 
Jak wspomniano, w Korespondencji filomatów znalazło się 60 listów Jana Czeczota skierowanych do Mickiewicza (poeta odpowiedział na 43) — za rok 1819 jest ich 13, za 1820 - 15, w latach następnych: 1821 i 1822 już tylko 5 i 7 , natomiast $\mathrm{w} 1823$ roku — aż 20; do liczby tej można dodać jeszcze fragmenty 2 listów. Niestety, wskazanie jedynie najbardziej istotnych fragmentów związanych z osobowością przyjaciół zaburzyłoby już kompozycję niniejszej pracy (i zagadnienie to nie jest jej celem).

Analizy wymaga przecież nie tylko korespondencja Czeczota, ale i konfrontacja jego myśli z korespondencją Mickiewicza; nie należy też pozostawiać na boku częstokroć nie mniej ważnych listów pozostałych przyjaciół oraz bliższych i dalszych znajomych. Przedstawiają bowiem konteksty dotyczące lektur Czeczota i obserwowanego przezeń świata kultury, obyczajów i polityki (przykładowo Warszawy). Przede wszystkim jednak warte są odnotowania z racji opisywanych tam prób poetyckich oraz ich oceny przez samego Mickiewicza. Zwłaszcza jego uwag wobec rywalizacji Czeczota i Zana, a dotyczących ballady, gatunku, którego niebawem stanie się mistrzem ${ }^{19}$.

Listy obejmują również kwestie wydawałoby się marginesowe, a w niedalekiej przyszłości kluczowe w biografii filomaty: to tak zwane niedostatki finansowe, gdyż załatwiając tak wiele spraw swoich i przyjaciół (od płótna na spodnie po pertraktacje z drukarzami, księgarzami i prenumeratorami), był odpowiedzialny za znacznie sumy, w tym kredytowe, które sięgały już nie setek, lecz tysięcy rubli ${ }^{20}$.

Zwłaszcza rok 1823 był dla niego wyjątkowo pracowity — oprócz książek dostarczanych na żądania Mickiewicza do Kowna większość czasu do wakacji spędza nad korektą drugiego tomiku, jedynie okazjonalnie wracając do własnej twórczości. Gdy pierwszy jest w przedruku, Grażyna w cenzurze u Lelewela, w tomiku drugim, w zgodzie z poprawkami Czeczota, pojawia się charakterystyczna zamiana Karusi (pierwowzór postaci w Dziadach) na „anielską” Zosię.

$\mathrm{Z}$ trudem zatem powracając do twórczości własnej, 8 kwietnia 1823 roku prosił przyjaciela:

${ }^{19}$ Całość (60 listów) ogłosił J. Czubek, Korespondencja..., passim. Wydawcy Listów do Adama Mickiewicza (oprac. M. Dernałowicz et al., t. 1, red. E. Jaworska, M. Prussak, Warszawa 2014) poszerzyli ten zbiór o dwa listy: [1.] Czeczot do Mickiewicza [Wilno, luty 1818-październik 1824] - s. 431 (kartka włączona do listu; Poezja filomatów, t. 1, s. 99); [2.] Czeczot do Mickiewicza, Wilno, 25 września 1819 - s. 444 (dopisek w liście Zana; Korespondencja..., t. 1, s. 124); zob. też A. Mickiewicz, Dzieła (wydanie rocznicowe 1798-1998), t. 14. Listy, cz. 1. 1815-1829, oprac. M. Dernałowicz, E. Jaworska, M. Zielińska, Warszawa 1998; tu edycja 44 listów (dodano list Mickiewicza do Zana i Czeczota; Korespondencja..., t. 2, s. 351); w t. 14 zamieszczono też jeden list poety z 1827 (do Czeczota i Zana), a w t. 15 list do Czeczota z 1830 roku.

${ }^{20}$ Zob. C. Zgorzelski, Materiaty do dziejów wileńskiej edycji „Poezyi”..., s. 625-651; s. 631, przyp. 13 (doskonale orientujący się w finansach Czeczot w korespondencji wszystkie kwoty wypisuje bądź w monetach Królestwa Polskiego z lat 1815-1830, złotych polskich (oznaczanych także konwencjonalnym znakiem florena), bądź kursujących w Rosji rublach srebrnych lub papierowych). 
Już teraz cię nie męczę twojemi korektami, ale swemi. Chcę sporządzić śpiewków edycyą do maja, z muzyką, ze wszystkiem. Czas krótki, trzeba prędko się zwijać. Gwałtem siebie przymusiłem do zrobienia nowej „Wandy”, bo pierwsza mi się samemu najgorszą ze wszystkich zdała. Myśl naciągnięta. [...] Bez ochoty, z musu przecież zrobiłem na nowo. Obacz, jak ci się zda.

Kolejny list, z 12 maja 1823 roku, ostatni z zachowanych w Korespondencji filomatów, jest równie zajmującym źródłem informacji. Czeczot wysyła drugi tomik Poezji do przebywającego w Berlinie Malewskiego i oprawione dwa drugie (jeden z dedykacją poety) do Bolcienik, informując Mickiewicza: „[Maryla] zaprasza mię na wieś, zaleca zdrowe powietrze i konia. Nie potrzeba zapraszać i zalecać; jakby tylko można, chcę być. W którąś także niedzielę będę tam, może dni parę zabawię".

\section{Proces filaretów, więzienne listy i carski wyrok}

Po aresztowaniu rektora Twardowskiego i wszczęciu śledztwa pod zwierzchnictwem senatora Mikołaja Nowosilcowa po Wilnie i okolicach rozeszła się fala represji i aresztowań. Czeczot, związany licznymi obowiązkami pracy w Prokuratorii Radziwiłłowskiej, na wakacje 1823 roku pozostał w mieście. Do rodziców udał się dopiero w pierwszych dniach sierpnia, a wracając do Wilna pod koniec tegoż miesiąca, mógł raz jeszcze odwiedzić Puttkamerów w Bolcienikach; w imionniku Maryli zachował się jego czterowiersz z 25 sierpnia 1823 roku, podpisany inicjałami „J.C.”

Wplątany fałszywymi zeznaniami przez Jana Jankowskiego, został aresztowany już 10 września 1823 roku jako pierwszy z filomatów; po nim wkrótce zatrzymano Zana, Jeżowskiego, Mickiewicza i innych. Osadzono go samotnie w klasztorze misjonarzy, dawnym kościele św. Kazimierza, następnie (mimo poręczeń Wawrzyńca Puttkamera) u franciszkanów na Łukiszkach, a na koniec, już po zakończeniu dochodzenia w czerwcu 1824 roku, razem z Zanem i Jankowskim u bazylianów. Drobiazgowe śledztwo objęło łącznie kilkuset studentów i uczniów klas gimnazjalnych, trwać miało blisko rok $^{21}$.

Jako przewodnik Grona Błękitnego stanął przed zarzutem działalności antyrządowej (utworzenie tajnego towarzystwa), ponadto wspólnie ze studentem Janem Jundziłłem miał potajemnie wydrukować u bazylianów (rozdany filaretom) Opis jeograficzny. Trzecim jego przestępstwem było pisanie i śpiewanie pieśni patriotycznych.

${ }^{21}$ Wiersz Czeczota w albumie Maryli, [w:] Księga pamiątkowa na uczczenie setnej rocznicy urodzin..., s. 336. Zeznania J. Jeżowskiego, po części dotyczące Czeczota, podał do druku H. Mościcki, Z filareckiego świata..., s. 3-28; we fragmentach S. Pigoń, Głosy z przed wieku. Szkice z dziejów procesu filareckiego, Wilno 1924; zob. też Z. Sudolski, Wkład filomatów i Mickiewicza w walkę o niepodległość (refleksja na 200-lecie urodzin Mickiewicza i 80-lecie odzyskania niepodległości), „Rocznik Towarzystwa Naukowego Warszawskiego” 6, 1998, s. 27-43. 
Czeczot pięciokrotnie odpowiadał na „zapytania” komisji śledczej: 10 października i 7 listopada 1823, a w roku następnym: 17 stycznia, 9 lutego i 19 kwietnia (dwukrotnie). Uczestniczył też w konfrontacjach składanych poprzednio zeznań z Janem Jankowskim i Stanisławem Marciejewskim ${ }^{22}$.

Dając uwięzionym przykład codziennej modlitwy (niejeden z filomatów nosił szkaplerzyk, Zan darował mu nawet własny krzyżyk), mimo wielu problemów nie poddał się uczuciom ubezwłasnowolnienia i nie wydał żadnego ze związkowych kolegów, ograniczając się wyłącznie do obrony własnej osoby. Odpowiadając na pytanie dotyczące Towarzystwa Wierszopisów, mówił: „Ja kiedy miałem czas dawniej do uczenia się i pisania, próbowałem czasem coś i wierszem napisać. [...] Były to: śpiewek o Barbarze Radziwiłłównie i kilka erotyków".

W sprawie istnienia innych towarzystw przyznał (zgodnie z prawdą), że oprócz „towarzystwa niedostatnich uczniów”, zajmującego się „wsparciem stołowym" studentów, skierowano go do Komitetu Egzaminacyjnego, który rozpoznawał ich postępy w nauce i przywołał działające w Wilnie otwarcie Towarzystwo Typograficzne, Towarzystwo Biblijne i Towarzystwo Medyczne.

W czasie procesu Czeczot nie przerwał działalności literackiej: na dzień 21 grudnia 1823 roku, imieniny Tomasza Zana, przesłał aż cztery teksty, pośród nich zapewne także wiersz Przemoc duszy nie złamie, mur nas nie rozdzieli. W podobnym tonie, $\mathrm{z}$ determinacją, pisał też w kolejnych swoich utworach (pieśniach), skierowanych do grupy więzionych u franciszkanów przyjaciół: $O$ ty, ziemio nieszczęśliwa! czy Wiersze do zamurowanej dziury włożone (,Żadne przemoce cnoty nie przygniotą, / Cnota i w samym więzieniu jest cnotą") ${ }^{23}$.

O charakterze tej i znacznie wcześniejszej, odtwarzanej już z pamięci, twórczości Czeczota zaświadczać mogą wspomniane manuskrypty zachowane w spadku

22 J. Borowczyk, Rekonstrukcja procesu filomatów i filaretów 1823-1824: historia śledztwa przeciw uczestnikom konspiracji studenckich i młodzieżowych $w$ Wilnie oraz $w$ Wileńskim Okregu Naukowym, Poznań 2003, passim; tu: Zapytania najdującemu się przy Komisji Radziwiłlowskiej Prokuratorii Janowi Czeczotowi dane z polecenia Jaśnie Wielmożnego Tajnego Radcy, Senatora i Kawalera Nowosilcowa - [1.] Pierwsze zeznanie Jana Czeczota, 10 października 1823 (s. 209-211); [1.1] „Oczna stawka” pomiędzy J. Czeczotem i J. Jankowskim, 12 października 1823 (s. 216-217) oraz [1.2] powtórna konfrontacja 18 kwietnia 1824 (s. 661-662); [2.] Drugie zeznanie Jana Czeczota, 7 listopada 1823 (s. 280-282); [3.] Trzecie zeznanie J. Czeczota, 17 stycznia 1824 (s. 447-454); [4.] Przestuchanie J. Czeczota w sprawie wierszy znalezionych w papierach Józefa Jeżowskiego, 9 lutego 1824 (s. 550-551); [5.] Na pytania komisji śledczej dwukrotnie odpowiada J. Czeczot, 19 kwietnia 1824 (s. 664-667); [5.1] „Oczna stawka” między S. Marciejewskim a J. Czeczotem, 20 kwietnia 1824 (s. 680-682); [5.2] w załącznikach między innymi: list J. Czeczota do M. Rukiewicza, z Wilna 13 września 1823 roku.

23 J. Czeczot, $O$ ty, ziemio nieszczęśliwa!, [w:] Listy z więzienia, t. 4, oprac. Z. Sudolski, Warszawa 2000 (522 s.; rec. (krypt. MM), „Acta Poloniae Historica” 85, 2002), s. 56-57; pieśń poprzedzającą (Żadne przemoce), w odróżnieniu od ustaleń, które przedstawił S. Świrko (Z Mickiewiczem pod rękę..., s. 196), wydawca Listów (s. 24 i 274) przypisuje odczytującemu wiersze filarecie A. Chodźce, sugerując możliwe autorstwo Czeczota w dwóch ostatnich anonimowych tekstach (zob. s. 57 i 59). 
po Zofii Malewskiej-Brochockiej, nazwane potem „małym archiwum filaretów”. Kierując się bowiem ustaleniami, które zaproponował Stanisław Świrko, można przyjąć, że „wszystkie trzy tomiki (poza kilkunastoma wierszami [...] w końcowej części zbiorku I) zostały napisane w więzieniu [około dwustu pozycji!], w klasztorze franciszkanów na przełomie lat 1823 i 1824”.

Zapewne najwcześniej z nich powstał tomik pierwszy pod tytułem Zosine piosnki do nut piosnek narodowych gminnych zastosowane z muzyka (1823), po wierszu dedykacyjnym zawierający dwadzieścia piosnek numerowanych cyframi rzymskimi; w większości ułożonych do melodii narodowych (kręgu repertuaru środowiska drobnoszlacheckiego) bądź ludowych, które „Żeńcy w Nowogródzkim śpiewają".

Pośród nich znalazły się i takie, prawdopodobnie jeszcze z lat 1818-1819, pośród których źródłem inspiracji filomackiego poety (i jego kolegów) był modny wówczas krotochwilny poemat księdza Józefa Baki, postaci, nie bez ironii przez profesora Borowskiego określanej jako „nasz Milton sarmacki”, albowiem „wieśniak, dziecię, niewiasta; wszyscy go doskonale rozumieją, wszyscy z nim dzielą uniesienie" 24 .

Rękopis po nienumerowanej piosnce ostatniej, zamykającej zbiór wierszy (nie licząc późniejszych uzupełnień), zawiera prozaiczny Dodatek, o tyle istotny dla opisu twórczości i sylwetki jego autora, że jest jednym z pierwszych w dziejach naszej folklorystyki referatem (rozprawką) na temat zbierania pieśni ludowych.

Natomiast tomik drugi zatytułowany Śpiewki Zosine, zapisany w całości przez Czeczota prawdopodobnie od stycznia do marca 1824 roku, po krótkiej dedykacji zawiera cykl dwudziestu jeden śpiewek, oznaczonych tym razem cyframi arabskimi; w niektórych z nich znajdują się wyraźne filiacje tekstowe i nawiązania do Ballad i romansów oraz Dziadów Adama Mickiewicza. Po sentymentalnych wierszykach miłosnych następuje seria piętnastu erotyków (w tym anakreontyków recenzowanych przez Mickiewicza w 1821 roku), utrzymanych w konwencjonalnej poetyce klasycystycznej.

Po ostatnim Erotyku dla Maryni (starszej siostry Zosi Malewskiej) z 15 stycznia 1824 roku rozpoczyna się cytowany zbiór dwudziestu czterech trenów, pod wspólnym tytułem Obłakany. Bohater tych wierszy, jak można sądzić, nosi wyraźne cechy autora, poddane stylizacji poetyckiej (wewnętrznych sprzeczności), kreującej zaprezentowaną postać jako bohatera romantycznego. Cały poemat

${ }^{24}$ S. Świrko, Z Mickiewiczem pod rękę..., s. 196, 176, 183-184 (Dodatek) i 193 (Treny). Zob. także J. Baka, Uwagi o śmierci niechybney [...], (Wilno), druk. Jezuitów, 1766; Uwagi o śmierci niechybney [...]. Drugi raz nakładem Amatorów [...] na nowo przedrukowane, (Wilno), druk. J. Zawadzki, 1807; tu wierszowana dedykacja L. Borowskiego; następnie idem, Porównanie życia Szurłowskiego i Baki, na wzór Plutarcha, „Tygodnik Wileński” 9, 1820 nr 154-155; zob. też A. Nawarecki, Czarny karnawat: ,,Uwagi śmierci niechybnej” księdza Baki - poetyka tekstu i paradoksy recepcji, Wrocław 1991. 
może być przykładem wyrobionego smaku artystycznego autora i najbardziej interesującym utworem w piśmiennictwie więziennym Czeczota:

Gorę - płonę jak Feniks własnymi skrzydłami,

Między niebem i ziemią miotając ogniami.

I nie wiem, skąd mi płyną melodyjne tony,

Nim nie będę mym ogniem w popiół przetrawiony!

Bądź szczęśliwy! — któż to rzekł? Kto tak bluźnił srodze

Bogu, który po twardej kazał mi iść drodze?

Podobne wartości artystyczne, choć o odmiennej, bo miłosnej już naturze, odnaleźć można w tak zwanym Raptularzu Czeczota (cząstka jego twórczości z lat 1818-1824), w którym nieznanym charakterem pisma zapisano jego kolejny utwór Nowa Sofiówka. Wiersz do Zosi (1823). Tekst, oddający hołd twórczości Stanisława Trembeckiego, skierowany jest jednak nie w stronę fantazji literackiej, której Czeczot starał się unikać, lecz osnuty na konkretnych „wileńskich” realiach (,zbierałem agrest"); podkreśla też, co dopiero staje się charakterystyczne dla autora, wyższość moralną poety oraz (także tylko w autorskich zamysłach) skromnej rektorówny.

W zakresie sylwetki biograficznej można odnotować, że wiersz ten prezentuje Czeczota jako rozmiłowanego w urokach wsi ziemianina, $\mathrm{z}$ uzupełnieniem, że na jego „literackiej postawie” zaważyły w równej mierze tradycje staropolskie Jana Kochanowskiego oraz rodzinne, a dopiero dalej wartości wyniesione z lektury dzieł Jana Jakuba Rousseau, albowiem dom rodzinny z jego tradycją niepodległościową, wartościami i wzorcami oraz tak intensywnie przeżywana miłość to najczęstsze azyle, w których także on znalazł wówczas schronienie przed ponurą rzeczywistością; przykładem są koleżeńskie treści, które w styczniu 1824 roku zapisywał Antoni E. Odyniec w Pieśni filaretów:

Gdy uwielbień godna cnota,

któż poczciwszy nad Czeczota?

Więc, panowie, jego zdrowie,

wiwat Czeczot Jan!

W maju 1824 roku wydano zamykające proces orzeczenie: za „szerzenie nierozsądnego polskiego nacjonalizmu przez pośrednictwo nauki" 166 osób uznano za winnych, trzy miesiące później car zatwierdził wyrok, przedstawiony na nadzwyczajnym posiedzeniu rady uniwersyteckiej: Tomasza Zana skazać na rok twierdzy, „Jana Czeczota i Adama Suzina, którzy w wierszach i mowach publikowali szkodliwe zamiary, po wytrzymaniu ich przez 6 miesięcy w twierdzy, wysłać z polskich, w rosyjskie gubernie, dopóki nie nastąpi decyzja względem powrotu ich do swojej rodziny"25.

${ }^{25}$ A.E. Odyniec, Pieśń filaretów [w styczniu 1824], [w:] Poezja filomatów, t. 1, s. 154-156. Raport M. Nowosilcowa dla wielkiego księcia Konstantego (dat. 13 maja 1824 r.) opublikował w oryginale T. Wierzbowski w czasopiśmie „Warszawskija Uniwiersitietskija Izwiestija” 1897, z. 8-9 (odb. Warszawa 1898); przekład polski A. Krechowiecki, Prawdy i bajki, Warszawa 1911, s. 125-317; J. Borowczyk, Rekonstrukcja procesu..., s. 695-707. 
Ogółem dziesięciu filomatów i dziesięciu filaretów wysłano na przymusowy pobyt $\mathrm{w}$ głąb Rosji, a osiemdziesięciu ośmiu, choć zwolniono z aresztu, oddano pod bezpośredni dozór policji. Represje nie ominęły profesorów Uniwersytetu Wileńskiego i uczniów szkół akademickich, oprócz Wilna najbardziej ucierpiało gimnazjum w Krożach, na Żmudzi (działał tam związek Czarnych Braci).

Tuż przed wyjazdem na jednym z pożegnalnych spotkań w celi bazyliańskiej u Tomasza Zana, Adama Suzina i Jana Czeczota ten ostatni zanucił przy gitarze „przez Tomasza akompaniującej” świeżo ułożoną piosnkę w dialekcie rusińskim „,z nadzieją i bez nadziei powrotu”; jest to zarazem okres ostatnich wpisów sztambuchowych. Każdy z zesłańców musiał też złożyć pisemną odpowiedź, czy będzie mógł się utrzymać z własnych środków. Czeczot nie prosił rządu carskiego o wsparcie, a cały jego majątek, który wiózł z sobą, to pochodzące z dobrowolnych składek 195 rubli w asygnatach.

Uzupełniając wcześniejszy podrozdział poświęcony filomackiej epistolografii, należy dodać, że niemal w całości zaginęła więzienna korespondencja Jana Czeczota, choć ta przedstawiona drukiem, obejmująca zaledwie dziesięciomiesięczny okres (od października 1823 do września 1824 roku), zbiera ogółem, oprócz utworów poetyckich, wcale pokaźną liczbę 146 listów. Na ogół ocalały listy (grypsy) pisane $\mathrm{z}$ więzienia, natomiast $\mathrm{z}$ uwagi na trwające śledztwo filomaci niszczyli odbierane przesyłki. Swoich przemyśleń w zakresie tak zwanej polityki i czasów, w których przyszło im żyć, też nie artykułowali zbyt często. W świadomości młodych ludzi otrzymana po przodkach ojcowizna to przecież nadal ziemie polskie, tylko teraz pod dominacją moskiewską ${ }^{26}$.

Nazwisko Czeczota w korespondencji więziennej pojawia się jednak często odnośnie do zróżnicowanej problematyki: od kwestii rodzinnych, dylematów uczuciowych, spraw organizacyjnych do przeżywania trudów odosobnienia i kształtowania się charakterów.

Natomiast z jego listów zachował się tylko jeden, skierowany do przebywającego na wolności Pietraszkiewicza, który uniknął wprawdzie aresztowania, lecz nie zamykającego ten proces wyroku. Na początku czerwca 1824 roku pisał:

${ }^{26}$ Przytaczane fragmenty listów znajdują się w ostatnim tomie Listów z więzienia, t. 4, passim; w kolejności wykorzystanych źródeł: J. Czeczot do O. Pietraszkiewicza [Wilno, początek czerwca 1824] — s. 369; następnie z tegoż tomu — [1.] T. Zan do O. Pietraszkiewicza [Wilno, koniec października/początek listopada 1823] - s. 98; [2.] T. Zan do S. Kozakiewicza i M. Puttkamerowej(?) [Wilno, początek grudnia 1823] — s. 104; [3.] T. Zan do O. Pietraszkiewicza [Wilno, 10 grudnia 1823] — s. 111; [4.] T. Zan do S. Kozakiewicza i J. Czeczota [Wilno, 14 grudnia 1823] — s. 119; [5.] T. Zan do O. Pietraszkiewicza [Wilno, 18 grudnia 1823] — s. 128; [6.] T. Zan do J. Czeczota [Wilno, 24 grudnia 1823] — s. 141; [7.] T. Zan do O. Pietraszkiewicza [Wilno, 25 grudnia 1823] s. 145; [8.] T. Zan do O. Pietraszkiewicza [Wilno, 11-12 kwietnia 1824] — s. 186; [9.] T. Zan do O. Pietraszkiewicza [Wilno, 13-15 kwietnia 1824] — s. 191; [10.] T. Zan do O. Pietraszkiewicza [Wilno, 28 kwietnia 1824] — s. 202; [11.] T. Zan do O. Pietraszkiewicza [Wilno, 29 kwietnia 1824] — s. 206; [12.] T. Zan do F. Malewskiego [Wilno, 4 maja 1824] — s. 213. 
Kochany Nufrze! Trzeba to już jakkolwiek skończyć, cośmy nie myśląc o końcu poczęli. Proszę Cie w tych dniach (kiedy Ci i Fr[anciszek] nie przeszkodzi pomówić z siostrą [Zosią]), poprosić jej, aby moje listki zebrała i do przejrzenia, jak już prosiłem, przysłała. Zrobić to prędko, bardzo prędko proszę, a niezawodnie będziesz miał powiastki lub co innego.

Przesyłka do wypróbowanego przyjaciela zawierała także wiersz, datowany 5 lutego 1818 roku, na zawiniątku z ,anielskimi” włosami Zofii Malewskiej Do M. S.:

Złote włosy tu się mieszczą,

Co uczucia moje pieszczą,

A choć smutku są przyczyną,

Zawsze z nich rozkosze płyną.

Pośród pozostałej korespondencji związkowej z pewnością warto wskazać na listy Tomasza Zana (dwa z nich zostały napisane do Czeczota) oraz filomaty Kazimierza Piaseckiego. Wydawać by się mogło, że informacje pierwszego z nich będą na swój sposób stronnicze (,skarży się z bied swoich, długów, miłości i Adama”), jednakże w ocenach działań przyjaciela zachował daleko idącą powściągliwość. Z kolei najbardziej pokaźny zespół listów wyszedł spod pióra Kazimierza Piaseckiego, adwokata sądów wileńskich, trzeźwo oceniającego nie tylko miłosne perypetie Czeczota ${ }^{27}$.

Jakże trafna pozostaje jego uwaga w liście z lutego 1824 roku do Jana Wysockiego, filarety i studenta prawa:

Nufra prosi Janko, aby matkę jego nauczył, jak ma się znaleźć przy podaniu prośby, szczególniej żeby jak najmniej mówiła, bo u nich nic nie waży słowo, a wszystko zapewna w prośbie wypisze Salmonowicz. Oni czułości macierzyńskiej języka nie rozumieją, a uniesienia matce bardzo łatwo popełnić.

Ze względu na wysoki wyrok już 10 października 1824 roku klasztorne mury opuścili Czeczot z Zanem i Suzinem. Pod eskortą żandarmów wyruszyli kibitką do wyznaczonych im twierdz we wschodnich terenach imperium. Po dwóch miesiącach (to ponad dwa tysiące kilometrów), około 20 listopada 1824 roku,

${ }^{27}$ Korespondencja (Listy z więzienia, passim) w kolejności wykorzystanych źródeł: [1.] K. Piasecki do Pietraszkiewicza [Wilno, 9 listopada 1823] — s. 237; [2.] Do filomatów [Wilno, 29 listopada-1 grudnia 1823] — s. 239; [3.] Do Pietraszkiewicza [Wilno, około 15 grudnia 1823] — s. 267; [4.] Do Pietraszkiewicza [Wilno, około 19 grudnia 1823] — s. 269; [5.] Do J. Wysockiego [Wilno, 22 grudnia 1823] — s. 273; [6.] Do Pietraszkiewicza [Wilno, około 26 grudnia 1823] — s. 280; [7.] Do Pietraszkiewicza [Wilno, 17-18 stycznia 1824] — s. 304; [8.] Do Pietraszkiewicza [Wilno, 21 stycznia 1824] - s. 305; [9.] Do J. Wysockiego [Wilno, początek/połowa lutego 1824] — s. 309; [10.] Do Pietraszkiewicza [Wilno, 20 lutego 1824] — s. 315. Wilnianin Kazimierz Piasecki nazywa, pochodzącego z Galicji, filaretę Mariana Piaseckiego „bratem” na oznaczenie łączących ich „braterskich” więzi związkowych, ale nie w znaczeniu tak bliskiego stopnia pokrewieństwa, jak określają tę postać wydawcy korespondencji więziennej (s. 235) i kolejnych tomów Listów z zestania; zob. Z.J. Nowak, Piasecki Kazimierz (1798-1882), [w:] PSB, t. 25, Wrocław 1980, s. 782; S. Kosiński, Piasecki Marian (1796-po 1840), [w:] PSB, t. 25, s. 785. 
dotarli do miejsca przeznaczenia, Orenburga, miasta położonego nad rzeką Ural, na granicy Europy i Azji.

Zan przez rok pozostać miał w tutejszej twierdzy, Suzin został skierowany do fortecy w Orsku (około $270 \mathrm{~km}$ od Orenburga), Czeczot do odległego o ponad 300 km Kizyla (Uralsk, rejon Orska). Gdy Suzin dalsze swoje losy dzielił z Zanem, Czeczot przebywał w tym czasie w Ufie, w północnej części guberni orenburskiej (blisko $500 \mathrm{~km}$ od Orska), liczył sobie wówczas 28 lat. Na wygnaniu spędzi kolejnych siedemnaście.

\section{Na zesłaniu (Kizyl, Ufa, Torżok i Lepel)}

Edycja pierwszego tomu $\mathrm{Na}$ zesłaniu pod redakcją Czesława Zgorzelskiego w 1973 roku, w założeniach będąca kontynuacją Archiwum filomatów, mogła stać się podobną rewelacją naukową i czytelniczą jak starannie wydane przed ponad półwieczem tomy Korespondencji Jana Czubka.

Niestety ingerencja cenzury w śladowy nakład 640 egzemplarzy Polskiej Akademii Nauk i zawieszenie dalszych prac spowodowały, że informacje dotyczące głównego bohatera tomu Onufrego Pietraszkiewicza oraz osób mu najbliższych mogły się stać przedmiotem zainteresowania niewielkiej grupy badaczy, a w konsekwencji jedynie „ustaleń wstępnych”, dotyczących również Jana Czeczota, gdyż zamieszczono tam (w pierwodrukach) trzynaście listów jego autorstwa ${ }^{28}$.

Na kolejne tomy przyszło czekać aż do 1997 roku, gdy po wielu trudach, tym razem edytorskich, przy nadspodziewanie owocnych kwerendach ukazały się Listy z zesłania jako czterotomowa, podejmująca chwalebny zamysł poprzednika, seria wydawnicza w opracowaniu redakcyjnym Zbigniewa Sudolskiego. Tom pierwszy, obejmujący Krag Onufrego Pietraszkiewicza i Cypriana Daszkiewicza, w korespondencji skierowanej do tegoż ostatniego, zawiera trzy listy Czeczota adresowane z Ufy (z lat 1827-1828) 29 .

28 Archiwum filomatów, t. 1. Na zestaniu, red. C. Zgorzelski, Wrocław 1973 (268 s.; rec. S. Świrko, Korespondencji filomatów ciag dalszy, „Rocznik Towarzystwa Literackiego im. Adama Mickiewicza" 10, 1975); tu 13 listów Czeczota z lat 1825-1830, wszystkie zaadresowane do O. Pietraszkiewicza; w Uzupetnieniach jeszcze dwa (1821-1823). Pierwsze w kolejności chronologicznej: [1.] Czeczot do Pietraszkiewicza i Józefa Zawadzkiego, Kizyl, 22 X 1825 - s. 99; [2.] Do Pietraszkiewicza, Kizyl, 23 XII 1825 - s. 108; [3.] Kizyl, 21 I 1826 - s. 109; [4.] Ufa, 3 XI 1826 - s. 117; [5.] Ufa, 24 II 1827 - s. 122; [6.] Ufa, 16 XI 1827 - s. 126; [7.] Ufa, 23 VIII 1828 - s. 132; [8.] Ufa, 30 I 1829 - s. 145; [9.] Ufa, 20 III 1829 - s. 150; [10.] Ufa, 21 VII 1829 - s. 160; [11.] Ufa, 18 IX 1829 - s. 170; [12.] Ufa, 18 XII 1829 - s. 171; [13.] Ufa, 3 XII 1830 - s. 187.

${ }^{29}$ Listy z zestania, t. 1. Krag Onufrego Pietraszkiewicza i Cypriana Daszkiewicza, zeb. Z. Sudolski, Warszawa 1997 (470 s.; rec. J. Kolbuszewski, Archiwum filomatów, „Odra” 2001, nr 6); Listy z zestania, t. 2. Krag Tomasza Zana, Jana Czeczota i Adama Suzina, zeb. Z. Sudolski, Warszawa 1999 (600 s.; rec. P. Dudziak, Jestem zwierciadłem czasu..., „Nowe Książki” 2000, nr 3); Listy z zesłania, t. 3. Krag Franciszka Malewskiego i Józefa Jeżowskiego, zeb. Z. Sudolski, Warszawa 1999 (840 s.; rec. E. Szymanis, „, Obumarte teksty odżywaja”, „Nowe Książki” 2000, nr 7). Końcowy t. 4 
Tom drugi, przynoszący najwięcej materiałów, Krąg Tomasza Zana, Jana Czeczota i Adama Suzina, zbierał w dziale Pisma Jana Czeczota (1826-1827) dwa nieznane jego teksty literackie: Wiadomość o Janie Mieczkowskim konfederacie (relacja ze spotkania w 1826 roku z sybirakiem jako początek romantycznej recepcji Baru) oraz tekst Kolęda na Nowy Rok 1827, dedykowany zesłańcowi krożskiemu, Wiktorowi Iwaszkiewiczowi (wypisy ze Starego Testamentu, przykład romantycznego przeżywania Biblii).

Dział epistolografii Jana Czeczota wypełnia dwadzieścia pięć listów adresowanych do najbliższych towarzyszy niewoli, Tomasza Zana i Adama Suzina. Powstał w pierwszych latach zesłania, 1825-1830, i odzwierciedla jego nastroje w czasie pobytu w Kizylu i Ufie, zawiera też liczne cytaty z listów przyjaciół nadchodzących z Moskwy i Petersburga ${ }^{30}$.

Z kolei korespondencja Jana Czeczota do różnych adresatów (1823-1846) to zespół siedmiu listów adresowanych do wąskiego grona odbiorców: pierwszy, napisany jeszcze w Wilnie, do Michała Rukiewicza, trzy do Marii Puttkamerowej, jeden do jej brata Michała oraz dwa do Antoniego Edwarda Odyńca i bliskich z jego kręgu.

Wszystkie znaczyć będą wędrówkę filomaty (tym razem zesłańczą) po opuszczeniu Wilna aż do powrotu do kraju: Kizyl, Ufa, Lepel i Bartniki. Pośród listów różnych osób do Czeczota $\mathrm{z}$ lat zesłania zachowały się tylko nieliczne: $\mathrm{w}$ edycji

Archiwum filomatów to Listy z więzienia w oprac. Z. Sudolskiego (Warszawa 2000). W t. 1 Listów z zestania, passim; w kolejności chronologicznej: [1.] Czeczot do Daszkiewicza, Ufa, 24 lutego 1827 - s. 363; [2.] Ufa, 27 kwietnia 1827 - s. 364; [3.] Ufa, 12 lipca 1828 - s. 381.

${ }^{30}$ Listy z zestania, t. 2, passim; w kolejności wykorzystanych źródeł: [1.] Wiadomość o Janie Mieczkowskim, konfederacie - s. 455; [2.] Kolęda na Nowy Rok 1827 - s. 463; Listy J. Czeczota do T. Zana i A. Suzina: [1.] [Kizyl], 24 grudnia 1825 - s. 468; [2.] [Kizyl], 1 stycznia 1826 s. 471; [3.] [Kizyl], 7 stycznia 1826 - s. 472; [4.] [Kizyl], 14 stycznia 1826 - s. 475; [5.] [Kizyl], 20 stycznia 1826 - s. 480; [6.] [Kizyl], 27 lutego 1826 — s. 483; [7.] [Kizyl], początek/połowa marca 1826 - s. 484; [8.] [Ufa], 27 kwietnia 1826 - s. 485; [9.] [Ufa], 11 maja 1826 - s. 489; [10.] [Ufa, 18] maja [1826] — s. 491; [11.] [Ufa], 3 sierpnia [1826] — s. 492; [12.] [Ufa] 7 września [1826] — s. 493; [13.] [Ufa], 21 kwietnia [1827] — s. 494; [14.] [Ufa], 18 maja [1827] — s. 495; [15.] [Ufa], 25 maja [1827] — s. 496; [16.] [Ufa], 3 lipca [1828] — s. 496; [17.] [Ufa], 29 sierpnia [1828] — s. 497; [18.] [Ufa], 29 września [1828] — s. 500; [19.] [Ufa], 5 lutego [1830] — s. 502; [20.] [Ufa], 7 sierpnia [1830] — s. 503; [21.] [Ufa], 20 sierpnia [1830] — s. 505; [22.] [Ufa], 18 września [1830] — s. 506; [23.] [Ufa], 2 października [1830] — s. 508; [24.] [Ufa], 22 października 1830 - s. 509; [25.] [Ufa], 27 listopada [1830] — s. 511. Listy J. Czeczota do różnych adresatów: [1.] Do M. Rukiewicza, Wilno, 13 września 1823 — s. 512; [2.] Do Al. Mickiewicza, A.E. Odyńca i innych, [Kizyl, połowa 1825] — s. 513; [3.] Do M. Puttkamerowej, [Ufa], 8 października 1830 - s. 516; [4.] Do M. Wereszczaki, [Torżok, 25 stycznia 1833] — s. 518; [5.] Do M. Puttkamerowej, Lepel, 14 marca 1836 - s. 518; [6.] Do M. Puttkamerowej, Lepel, 22 maja 1836 - s. 519; [7.] Do A.E. Odyńca, [Bartniki, 18 stycznia 1846] — s. 520. Następny zespół to 5 listów Czeczota do hr. Konstantego Tyszkiewicza: [1.] [Bartniki, 28 grudnia 1844] — s. 523; [2.] [Bartniki, 20 sierpnia 1845] — s. 525; [3.] [Bartniki, 31 grudnia 1845] — s. 526; [4.] [Dołmatowszczyzna, 28 sierpnia 1846] — s. 529; [5.] [Dołmatowszczyzna, 25 września 1846] — s. 532. Listy różnych osób do J. Czeczota: [1.] Od M. Piaseckiego, [Wilno, 14 grudnia 1824] — s. 533 (do Czeczota i Suzina); [2.] Od Al. Mickiewicza, M. i K. Piaseckich i J. Frąckiewicza, [Wilno, 5 stycznia 1825] - s. 534. 
podano jedynie listy Mariana i Kazimierza Piaseckich z lat 1824-1825 (ostatni z dopiskami Aleksandra Mickiewicza i Jerzego Frąckiewicza).

Końcowy tom, trzeci, Krag Franciszka Malewskiego i Józefa Jeżowskiego, zawiera pięć listów Czeczota z lat 1822-1836 skierowanych do Franciszka Malewskiego, syna rektora, a brata ukochanej Zosi. Podobnie jak w tomach poprzednich należy zwracać uwagę na treści rozproszone i tak zwane ezopowe oraz konteksty interpretacyjne. Warto też pamiętać, choć to już inny temat, że wielu z zesłanych filomatów — przykładowo: Adam Suzin czy Tomasz Zan („,miłośnik kamieni”) zapisało się trwale w dziejach tej krainy, pozostawiając znaczący dorobek naukowy w jej badaniach przyrodniczych ${ }^{31}$.

W kizylskiej twierdzy Czeczot przebywał od 22 grudnia 1824 do 15 maja 1825 roku. Na przełomie stycznia i lutego 1826 roku w celu poratowania zdrowia dostał zgodę na przeniesienie do Ufy, gdzie pracował jako guwerner, a od 1828 roku objął posadę urzędnika (dopiero wówczas pozwolono mu wstąpić do służby państwowej).

Zdecydowanie mniej szczęścia mieli uczniowie szkoły w Krożach: w lutym 1824 roku wileński sąd wojskowy orzekł za winnych „nieprawomyślności wobec władz" Cypriana Janczewskiego, Jana Witkiewicza, Wiktora Iwaszkiewicza, Alojzego Pieślaka, Mikołaja Suchockiego i Feliksa Zielenkiewicza. Dwóch pierwszych, jako najbardziej winnych, skazano na karę śmierci, pozostałych na dożywotnie ciężkie roboty i zesłanie. Ostatecznie wyrok został złagodzony gimnazjaliści uratowali życie, podobnie jak inni wygnańcy zostali wcieleni do garnizonów stacjonujących na linii orenburskiej. Zakuci w ciężkie pudowe łańcuchy $(16,38 \mathrm{~kg})$, doświadczając po drodze wielu upokorzeń, do stacji przeznaczenia dotarli po blisko siedmiu miesiącach marszu.

W zesłańczej historii Polaków wyraźniej jawi się dziś los tych, którzy postawili tam swoje stopy już pod koniec XVIII wieku — około 15 tys. konfederatów barskich, z których część znalazła się w Kraju Orenburskim, rozlokowana w twierdzach okalających od północnego wschodu ziemie dzisiejszego Kazachstanu. Podobnie jak na Syberię tam również kierowano uczestników narodowych powstań (kościuszkowskiego), jeńców wojen polsko-rosyjskich (resztki wziętych do niewoli żołnierzy napoleońskich) i wreszcie rzesze niepokornych, walczących o uniezależnienie się od imperium; „Rosja granic na wschodzie nie ma” oznajmiło niebawem carskie Ministerstwo Spraw Zagranicznych ${ }^{32}$.

${ }^{31}$ Listy z zesłania, t. 3, passim, w kolejności chronologicznej listy J. Czeczota do F. Malewskiego: [1.] [Wilno, 11 stycznia 1822] — s. 445; [2.] Wilno, 30 maja 1823 - 519; [3.] [Lepel], 12 stycznia [1835] — s. 568; [4.] Torżok, 26 stycznia [1836?] — s. 574; [5.] Lepel, 1 lutego 1836 - 574. Zob. także M. Bednarczuk, Mierzenie imperium: Tomasz Zan między Wilnem a Orenburgiem, [w:] Georomantyzm: literatura, miejsce, środowisko, red. E. Dąbrowicz et al., Białystok 2015, s. $92-113$.

${ }^{32}$ B. Jędrychowska, Polscy zestańcy na Syberii (1830-1883). Działalność pedagogiczna, oświatowa i kulturalna, Wrocław 2000; Z. Sudolski, Mickiewicz wśród filomatów w więzieniu i na zesłaniu, [w:] Mickiewicz w Gdańsku. Rok 2005, red. J. Bachórz, B. Oleksowicz, Gdańsk 2006, 
Można zatem wnosić, że to nie w Wilnie, w celi Konrada, w poetyckim widzeniu autora i bohatera Dziadów drezdeńskich, ale tutaj, w apokaliptycznej rzeczywistości nieokiełznanego niczym infernum, teraz i w dziesięcioleciach następnych rozbrzmiewać miały prorocze słowa księdza Piotra: „Tyran wstał — Herod! - Panie, cała Polska młoda. Wydana w ręce Heroda”. Czeczot poznał ten świat dokładnie, $\mathrm{z}$ autopsji ${ }^{33}$.

Wracając do samych filomatów, na wynikającą z Listów z zesłania wielowątkową siatkę tematów, przynajmniej kilkuset autorskich bądź współautorskich zależności, dla przejrzystości przedstawianych tu treści należy nałożyć i choć w kilku zdaniach przybliżyć sylwetki przynajmniej kilku z nich ${ }^{34}$.

s. 13-30. Poniżej B. Zaleski, Polscy wygnańcy w Orenburgu, „Rocznik Towarzystwa Historyczno-Literackiego na 1866 rok" (Paryż) 1867, s. 75-107; idem, W stepach kirgiskich (z notatek Bronisława Zaleskiego), cz. 1-2, „Kronika Rodzinna” 1890, s. 622-623.

33 Źródłowo i w opisach analitycznych: W. Galijew, Istorija Kazachstana. Dorewolucjonnyj pieriod. Bibliograficzeskij ukazatiel, t. 1-2, Ałma-Ata 1988; W. Jewsiewicki, Stowarzyszenie „Czarnych Braci" w Krożach na Litwie i kazachstańskie losy jego członków, [w:] Polacy w Kazachstanie. Historia i współczesność, red. S. Ciesielski, A. Kuczyński, Wrocław 1996, s. 81-96; W. Śliwowska, Polacy na linii orenburskiej (pierwsza połowa XIX wieku), [w:] Polacy w Kazachstanie..., s. 69-79; A. Kijas, Polacy w Rosji od XVII wieku do 1917 roku: stownik biograficzny, Warszawa 2000.

${ }^{34}$ Pięcioletni okres pobytu Mickiewicza w Rosji (1824-1829) obejmuje kilka etapów: Petersburg (listopad 1824-1825); podróż na południe Rosji, Odessa i Krym (luty-listopad 1825); Moskwa (grudzień 1825-grudzień 1827); ponownie Petersburg (grudzień 1827-luty 1828) oraz Moskwa (luty-kwiecień 1828) i Petersburg (maj 1828-maj 1829). Jan Sobolewski opuścił Wilno wspólnie z Mickiewiczem, w Petersburgu złożył prośbę o przyjęcie na służbę w „wydziale inżynieryjnym”. Razem z Janem Heydatelem 21 czerwca 1827 roku awansował na podporucznika; wiosną 1828 roku przebywali w Petersburgu u Mickiewicza. Zmarł nagle w Archangielsku jesienią 1829 roku, być może wskutek tragicznego wypadku. Mickiewicz uczynił go, z nieżyjącym Cyprianem Daszkiewiczem i Feliksem Kułakowskim, adresatem dedykacji Dziadów cz. III Franciszek Malewski, po przybyciu do Petersburga, z Mickiewiczem i Jeżowskim wyruszyli do Odessy. Malewski nie uzyskał jednak pozwolenia na osiedlenie się i wyjechał do Moskwy; 12 grudnia 1825 roku przeniósł się tam z Odessy Mickiewicz. Odtąd aż do wyjazdu poety na Zachód, 15 maja 1829 roku, trzymali się przeważnie razem. W 1830 roku założył „Tygodnik Petersburski”, redakcję powierzając Józefowi Przecławskiemu. Żonaty od stycznia 1832 roku z córką Marii Szymanowskiej, Heleną, starszą siostrą Celiny, przyszłej Mickiewiczowej. Józef Jeżowski, razem z Malewskim i Mickiewiczem, przeznaczony został na nauczyciela w odeskim Liceum Richelieugo. W 1825 roku osiadł w Moskwie, gdzie objął obowiązki nauczyciela języków klasycznych. W 1828 wydał książkę Homeri Odysseae rhapsodiae sex (wznowienie: Moskwa 1831), a rok później, także w Moskwie, rozprawę O postepie badań filologicznych we względzie pism Platona. Z początkiem 1841 roku był już w kraju i można przyjąć, że uzyskał amnestię, mniej więcej równocześnie z Zanem i Czeczotem. Rzecz szczególna: w okolicznych kołach literackich nie spotkał się ani z uznaniem, ani z nadmierną życzliwością; „Filozof” lub „Mrukawy” to tylko dwa z jego dawnych filomackich przezwisk. Onufry Pietraszkiewicz, wówczas „Proboszcz” i „Stryjaszek”, w czasie śledztwa uniknął aresztowania (współtworząc komitet pomocy), do Petersburga przybył z początkiem listopada 1824 roku, lecz stolicę opuścił już w styczniu 1825 roku, udając się na stały pobyt do Moskwy; od kwietnia pracował tam w bibliotece uniwersyteckiej. Nadal troszczył się o rękopisy filomackie, zwłaszcza o teksty poetyckie Czeczota i Zana; sam też próbował wrócić do układania wierszy. Na początku kwietnia 1828 roku udał się na Litwę w interesach powierzonych mu przez nieznanego bliżej ziemianina; odwiedził między innymi 
W Orenburgu znajdowali się zesłańcy mający różne rodzaje wyroków. Filomaci i filareci zostali tu przysłani na bezterminowe zamieszkanie, z warunkiem wcześniejszego odbycia kary więzienia. Tworzyli wówczas wyraźną mniejszość pośród tutejszej społeczności — panowała jeszcze atmosfera liberalnej polityki Aleksandra I (przerwana wkrótce powstaniem dekabrystów, a od 3 września 1826 roku samodzierżawiem Mikołaja I). Przybyli tu uczniowie, studenci czy po prostu ludzie wykształceni byli bardziej przedmiotem zaciekawienia niż prześladowania. Powoli potrafili zdobyć szacunek i wyrobić bardziej pewne, określone „czynem” (tabelą rang) stanowisko pracy państwowej, wszyscy stanęli jednak wobec istotnego patriotycznego, lecz i alternatywnego wyboru.

Jako jeden z pierwszych zwrócił na to uwagę były zesłaniec Bronisław Zaleski (1820-1880), już w 1866 roku, podnosząc:

Czeczot był w Ufie, Suzin i Tomasz Zan w Orenburgu. W tych pierwszych nowych wygnańcach naszych, narysowały się zaraz dwa różne kierunki, dwa sposoby pojmowania obowiązków i zadania wygnańca polskiego w Rosji, które długo potem znajdowały naśladowców między rodakami.

Czeczot [...] postanowił unikać wszelkich z Rosjanami stosunków, ograniczając się tylko najzupełniej koniecznymi, które by mu jak najprędzej pozwoliły wrócić. Zan przeciwnie, nie unikał ich zgoła, wszędzie i zawsze odpowiadając wypiastowane i ukochane w duszy prawdy. [...]. Czeczot bojąc się, żeby go długo nie zatrzymano, jak będzie potrzebny, powiedział że nic więcej nie umie; uwierzono mu, a na podziękowanie przedstawiono do powrotu, $i$ on istotnie pierwszy ze wszystkich wrócił.

Czeczot utrzymywał ze współtowarzyszami wygnania stałą korespondencję, już w pierwszych listach prosząc: „Piszą, że Adam w drodze, jedzie do Moskwy [...] Jeżu, Franku ozwij się — teraz ja Was będę wołał. [...] Niemy Matematyk [Budrewicz] kiedyż się gadać nauczy”. Opisując zaś realia zesłania, 22 października 1825 roku pisał do Pietraszkiewicza:

Nie potrafię wystawić swojego stanu duszy i nie będę się starał, ale rzucony pomiędzy skały i stepy, jestem coś do nich podobny. Wszystko, co się zbliża, co otacza, kamiennym i drewnianym czyni; może to być, że tak się rozpalone żelazo hartuje [...]. Zacząłem się jednak krzątać koło Irvinga. Kilka artykułów w julii nie bardzo miłosiernie przetłumaczyłem [...]. Jeśli tu przyjdzie (czego nie daj Boże) zimować, Irvinga po polsku przez zimę ubranego może Wam pokażę. Z tego, co się nazywa poezyi, nad kilka westchnień do naszej drogiej, nic nie napisałem.

Sporo interesujących informacji zawiera też list do Pietraszkiewicza z 21 stycznia 1826 roku, tak jak poprzednie skierowany w zasadzie do wszystkich przyjaciól, w którego zakończeniu prosi o miniaturę Zosi (którą „przewyborny malarz” miał zrobić), aby mieć dla „oczu i serca zatrzymane jej oblicze”, oraz

Puttkamerów i Domeykę. Za zrzucone mu prowokacyjnie uczestnictwo w spisku 1831 roku został skazany na karę śmierci, zmienioną na dożywotnie osiedlenie na Syberii. Z partią 173 zesłańców odbył od 7 lutego do 4 lipca 1832 roku pieszo, etapami, drogę z Moskwy do Tobolska. W 1841 roku podjął tam pracę jako kancelista, z czasem stając się i tutaj ośrodkiem polskości. Uwolniony manifestem z 1856 roku, wrócił na Litwę w lipcu 1860 roku; zob. J. Borowczyk, Rekonstrukcja procesu..., s. 757-778 (Biogramy); idem, Zestane pokolenie. Filomaci w Rosji (1824-1870), Poznań 2014, passim; oraz A. Fieduta, Sjużety i komientarii, Wilno 2013, s. 9-22, 23-32. 
informuje, że otrzymał ,pozwolenie dla poprawienia zdrowia pojechać stąd do miasta guber[nialnego] Ufy" 35 .

Czeczot psychicznie wyjątkowo źle znosił pobyt na zesłaniu - popadł w swego rodzaju mizantropię i zatargi z przyjaciółmi, zwłaszcza gdy doszło do konfliktu z Mickiewiczem na tle krytycznej oceny jego bliskich stosunków z Rosjanami. Poeta, przesyłając mu do Ufy za pośrednictwem Zana Konrada Wallenroda (Moskwa 1828) wraz z wsparciem pieniężnym, pisał: „Może Janek przyjąć bez skrupułu; to są pieniądze uzyskane za Wallenroda". Czeczot pozostał jednak nieprzejednany, tym bardziej że w następnym roku dotarła do jego rąk edycja Mickiewiczowskich Poezji (Petersburg 1829), w której autor usunął poprzednią wileńską dedykację.

Równie gorzko więc puentował swoje myśli w rozmowie korespondencyjnej z 24 lutego 1827 roku z Pietraszkiewiczem, pisząc:

Onufry, inne nastają już czasy! Ty chcesz, żeby tak zawsze jak w domu pacowskim [w Wilnie] szumiano, śpiewano. Minęły te czasy, nowych nie umiem pojąć ani wyobrazić, ale gdy ich równie nie lubię, jak i kłoniącej do nich coraz większej podżyłości; wszakże to przeciw fali dmuchanie, ten jakiś za przeszłością opór, a każdy teraz chce płynąć swą drogą, bo już się oddalił z ojcowskiego domu.

W kolejnym, z 28 sierpnia 1828 roku, już po jego powrocie z krótkiego pobytu na Litwie, „obrzydły już wszystkim [swoim] jęczeniem” zaznaczał:

Za wieści przywiezione dziękuję, zagrzały mi skrzepłe serce i nieżywe serce [...]. Co to się dzieje z Bolcienikami? gdzie będą dziedzice, jeśli je rozdzielą eksdywizorowie? Miałeś być w Mereczu, nie byłeś; czy nie słyszałeś jednak chociażby słowa o Zosi? Donieś cokolwiek i pisz, bo masz o czym pisać, ja nie mam wcale niczego. Deszcz, zegarek i serce tylko kołace.

Oprócz utrapień i zmartwień wygnańczego bytowania u wszystkich filomatów zadziwiać jednak może uporczywe poszukiwanie wiedzy, poparta starannie dobraną lekturą analiza otaczającej ich rzeczywistości, nie tylko przyrodniczej, lecz także społecznej, choć Czeczot także zebrał „skrzyneczkę kamieni”. To jakby dalszy ciąg związkowych zebrań, już nie w Wilnie, lecz tysiące kilometrów dalej, w zesłańczej teraźniejszości.

Do obserwacji Czeczota jeszcze o sprawie istotnej — o „starcu, który go bardzo zajął”, pisał do Onufrego Pietraszkiewicza 21 lipca 1829 roku, jak zwykle przeplatając tekst wzmiankami o wybrance serca:

${ }^{35}$ W. Irving (1783-1859), Rysy moralności i literatury albo Postrzeżenia we względzie obyczajów, zwyczajów i literatury Anglików i Amerykanów, przez Waszyngtona Irwinga po ang. napisane; a z 4. wyd. na pol. jęz. przełożone, t. 1-2, Wilno: druk. B. Neumana, 1830 (298 i 326 s.; anonim.; „Kuryer Litewski” 1829, nr 41: „cena prenumeraty na oba tomy 10 złp.”; „Z polecenia thumacza, wydawca. Ferdynand Gut”). Czeczot okazał się wyjątkowo sumiennym translatorem (choć przekład spotkał się z ostrą krytyką Jeżowskiego), wiernie oddając treść i formę stylistyczną oryginału, mimo że w swojej pracy posługiwał się wersją francuską; na uwagę zasługuje też staranność przypisów, odnoszących się do osób, dzieł i zjawisk życia angielskiego; zob. Z. Sinko, Polska recepcja twórczości Washingtona Irvinga: między Oświeceniem a romantyzmem, „Pamiętnik Literacki” 1988, z. 4. 
Przesyłam Ci żywot konfederata Mieczkowskiego, który możesz nie tylko przeczytać, ale i przepisać, jako ochotnik do przepisywania; potem odeszlij go z dołączającym listkiem do [filarety] Jerzego Frąckiewicza, którego ma on być własnością. [...] Zosia dobra, nie zapomniała o nas, mnie podstawkę pod szklankę z włoczki bardzo pięknie zrobioną za piosnki tatarskie przysłała.

Kilka miesięcy później, 18 grudnia 1829 roku, dodawał: „Posłałem [...] pod adressem [filarety Jana] Wiernikowskiego 15 rubli as[yg]. przeznaczonych na pomnik książecia Józefa [...], abyś z tymi, które sam może zbierzesz, do Warszawy odesłał".

Poprzez filomackie listy z zesłania przewijają się zatem nie tylko liczne „motywy książkowe”. Korespondencja ta ma wagę dokumentu potwierdzającego dotychczasowe ustalenia literaturoznawcze o istocie filomatyzmu: prezentuje, zwłaszcza na przykładzie Czeczota, postawę osoby mocno związanej z ideałami młodzieńczego związku, które dla jego przedstawicieli i wychowanków (filaretów) stały się nakazem wszelkich działań. Dzięki poszczególnym zespołom korespondencji zebranym w Listach z zesłania można zdecydowanie bliżej przyjrzeć się trwałości więzów wypracowanych w ciągu zaledwie kilku lat aktywności ogromnej użyteczności społecznej i organizacyjnej, w pełni dojrzałej działalności na rzecz służby nauce i zasadom patriotyzmu. Siemion S. Łanda w następujący sposób charakteryzował to pokolenie:

Wyrwani z ziemi ojczystej rozrzuceni byli po całym obszarze Rosji od Archangielska do Astrachania, od Petersburga i Moskwy do Kazania i Orenburga. Świetnie zapowiadający się historyk musiał zadowolić się skromną rolą kasjera w Banku Asygnacyjnym, utalentowani filologowie stawali się drobnymi urzędnikami, kancelistami. Poniżająca zależność, często prawdziwa nędza zaglądały w oczy wielu dawnym filaretom i filomatom.

\section{Sprzeciw przyjmował niekiedy formy krańcowe:}

Narodowa niechęć Jana Czeczota była na przykład tak silna, że potępiał on Tomasza Zana za przyjacielskie stosunki z niektórymi rosyjskimi rodzinami w Orenburgu. „Stołowicki” patriotyzm Czeczota głęboko niepokoił Mickiewicza, dla którego „kwestia rosyjska” była przedmiotem złożonych etycznych i historycznoliterackich dociekań ${ }^{36}$.

${ }^{36}$ W 1826 roku Mieczkowski liczył sobie 87 lat; zob. Z. Sudolski, Jan Mieczkowski sybirak-konfederata, czyli u początków romantycznej recepcji Baru, „Napis” 1999. Pomnik ks. Józefa Poniatowskiego, dłuta B. Thorvaldsena (1770-1844), zrealizowany został w latach 1829-1832, „Kurjer Warszawski” 1829, nr 181; Korespondencja filomatów..., t. 2, s. 286, 347; o dalszych losach zob. A. Kraushar, Posąg Thorvaldsena księcia Józefa jako echo walki klasyków z romantykami, Warszawa 1913. Zob. także S.S. Łanda, Do jednego ze „spótuczniów, spótwięźniów, spótwygnańców..." (nieznana improwizacja Mickiewicza), przeł. M. Biernacka, [w:] Na zesłaniu..., s. 205-217; Z. Sudolski, „Narodowej sprawy męczennicy” (o adresatach dedykacji „Dziadów” części III), „Pamiętnik Literacki” 1998, z. 1; oraz Między Ufą a Warszawa (1828). Jana Czeczota piosnki i listy z zestania do Antoniego Edwarda Odyńca, [w:] idem, Tropem detektywa: studia, materiały, sylwetki, t. 1, Warszawa 2009, s. 102-114. Pośród bardziej radykalnych filaretów pojawiały się głosy aprobujące postawę Czeczota, dodające do moskiewskiego wizerunku poety przysłowiową łyżkę dziegciu; zob. J. Wysocki do S. Kozakiewicza. Warszawa, 8 lutego 1826 (Listy z zestania, t. 1, s. 292) — „Poezyje Czeczota zebrać z muzyką: u Zosi ich przepaść z ostatnich czasów [...] Czeczot ma dużo prawa, aby mu kiedykolwiek Adam wydatki nagrodził, gdy zwłaszcza teraz z jenerałami szampańskie pije. Czeczota zaś potrzeby musiały diabelnie wygłodzić”. 
Swoje obowiązki wobec narodu i ojczyzny Jan Czeczot traktował bardzo poważnie: szczery i bezpośredni w stosunku do przyjaciół, skłonny do refleksji i zamykania się w sobie, wierny i bezkompromisowy wobec raz przyjętych ideałów i zasad, cały wolny czas poświęcał wyłącznie pracy, unikając jakichkolwiek stosunków towarzyskich z Rosjanami.

Okres więzienny z pewnością nadszarpnął jego zdrowie, dla którego poratowania uzyskał zgodę na wyjazd, na początku 1826 roku, do miasta gubernialnego Ufy. Tu stołując się u miejscowej „kupczychy”, zapraszał zawsze listownie któregoś z kolegów, aby dobrze zjeść i po przyjacielsku (korespondencyjnie) się nagadać. Po dostarczeniu rodowodu szlacheckiego w 1828 roku uzyskał zezwolenie na wstąpienie do służby państwowej, co znacznie poprawiło jego sytuację finansową.

Najserdeczniejsze listy kierował w tym czasie do Pietraszkiewicza, pełniącego funkcję centrali korespondencyjnej zesłańców. Najwcześniej ustała wymiana listów z Malewskim ze względu na liczne zapytania o losy jego sióstr. Z kolei z Zanem łączyła się sprawa, która zatruła i tak niełatwą ich dolę - nieszczęśliwa miłość obu wygnańców do Zosi, u Zana przeradzająca się w mistyczną egzaltację; do czasu gdy pojawiła się Żenia (Joanna), córka generała Żemczużnikowa, którego synkowi udzielał korepetycji. Na podstawie korespondencji można wskazać również przynajmniej kilka przykładów powstałej w tym czasie twórczości poetyckiej - pośród wierszy miłosnych, czyli filomackiej erotyki, jest to jeden z wierszy z okresu jego pobytu w Ufie, Marzenie nad brzegiem Białej z 16 kwietnia 1828 roku, oraz noszący w sobie podobny smutek zesłańca utwór Wędrowna ptaszyna.

Rok 1830 był w życiu Czeczota okresem przełomowym, gdyż 13 maja tegoż roku otrzymał zezwolenie na osiedlenie się w centralnych guberniach rosyjskich. Złożył oświadczenie, że pragnie zamieszkać w Moskwie lub Petersburgu i ubiegać się o przyjęcie do służby w dziale bankowości. Z Ufy wyjechał do Moskwy w końcu grudnia przez Orenburg, gdzie chciał się pożegnać z Zanem i Suzinem. Pełen nadziei wiózł do moskiewskich przyjaciół jako plon swego sześcioletniego zesłania, oprócz dwóch tomów Irwinga, sporą garść pieśni i erotyków, w tym gotowy rękopis Śpiewów historycznych o znakomitych Polkach; była to realizacja zamiaru podjętego w Wilnie w 1823 roku, wzorowana na Śpiewach historycznych Niemcewicza.

Czeczot nie znał wydarzeń listopadowych rozgrywających się w Królestwie Polskim, gdyż informacje o nich nie zdążyły jeszcze dotrzeć do guberni orenburskiej. Już po jego wyjeździe nadeszło z Ministerstwa Spraw Wewnętrznych pismo z 18 lutego 1831 roku, potwierdzające zezwolenie na osiedlenie w guberniach centralnych, ale z wyłączeniem Moskwy i Petersburga. Czeczot był już w Moskwie, nieustannie szukał pracy, a nie znalazłszy jej, wyjechał do Tweru 9 czerwca 1831 roku. Mieszkał zatem w Moskwie ponad cztery miesiące, niewątpliwie musiał spotkać się z Pietraszkiewiczem, lecz gdy nastroje antypolskie zaczęły wzrastać, 
postanowił wyjechać. W mieście nie było już zresztą dawnego grona przyjaciół: Mickiewicz wyjechał za granicę, Malewski od kilku lat przebywał w Petersburgu, Jeżowski był w Kazaniu, a Cyprian Daszkiewicz zmarł w grudniu 1829 roku.

Twer nie okazał się bardziej gościnny niż Moskwa. W mieście panowała epidemia, a podejrzenia tutejszej ludności o zatruwanie studni (wzmocnione informacjami o toczącej się w Królestwie Polskim rewolucji) kierowały się również w jego stronę. Chcąc uchronić wygnańców od napaści tłumu, gubernator upozorował ich aresztowanie. W czasie tych zamieszek Czeczot poniósł niepowetowaną stratę — zaginął bezpowrotnie jego rękopis Śpiewów historycznych.

Po zwolnieniu z dozoru policyjnego, w 1831 roku, przeniesiono poetę z Tweru do miejscowości Torżok w guberni twerskiej. Zmianę adresu potwierdza list Czeczota do Michała Wereszczaki, datowany na 25 stycznia 1833 roku, w którym informował, że źle się czuje w nowym miejscu oraz o wysłaniu Maryli zbiorku swych pieśni; wspomniany w liście „seksterniczek śpiewków” nosił tytuł Zosine piosnki $i^{37}$.

Do grupy cenniejszych liryków tego czasu należy choćby piosnka XIII (Kochać Ojczyznę i Zosię...), łącząca niezwykłą melodyjność i oszczędność słowa. Wiersz liczy zaledwie trzy zwrotki, a tematem i motywem głównym całego zbiorku są „dwie kochanki”. Z kolei wiersze (piosnka XVIII i XIX) są przykładem tak dobrze znanej filomatom poezji społecznej (programowej), głoszącej hasła pracy dla dobra narodu, i upamiętniają, oczywiście bez żadnych wskazań, okres powstania listopadowego, które w czasie pobytu Czeczota w Twerze i Torżku dobiegało tragicznego finału.

Dzięki wstawiennictwu gubernatora Tweru Czeczot uzyskał posadę sekretarza przy zarządzie inżynieryjnym Kanału Berezyńskiego w Leplu, dokąd przeniósł się w 1833 roku. Co istotne, miasto i ziemia witebska, chociaż włączone do guberni rosyjskich, leżały już na przedrozbiorowych terenach Rzeczypospolitej. Zamieszkiwało tu znacznie więcej Polaków i filomata-poeta mógł się oddać swo-

37 C. Jankowski, Czeczot i Zan w Leplu: notatka biograficzna, [w:] Z ziemi pagórków leśnych, z ziemi łąk zielonych: ksiązka zbiorowa poświęcona pamięci Adama Mickiewicza w stuletnia rocznice jego urodzin 1798-1898, Warszawa 1899, s. 35-43; S. Świrko (Z Mickiewiczem pod rękę..., s. 310 w przyp. 2) nadmieniał ,autor podaje też mylnie, iż razem z Czeczotem był w Twerze Suzin (w rzeczywistości pozostał w Orenburgu). Tomasz Zan przebywał w Leplu w 1844 roku (już po ogłoszeniu amnestii w 1841 roku) jako lustrator dóbr rządowych, a więc trzy lata po wyjeździe Czeczota". Przesłanego Maryli zbiorku nie należy mylić z rękopisem Zosinych piosnek z okresu uwięzienia filaretów: ten ostatni (przedtem w teczce zbiorów po J. Kwietniewskim) odnalazł się po ostatniej wojnie w Muzeum Literatury w Warszawie, opisali go L. Podhorski-Okołów (Realia Mickiewiczowskie, s. 69-70) i S. Świrko (Z Mickiewiczem pod rękę...), s. 234-240. Przedstawiony zaś manuskrypt jest autorską repliką, a pierwszy egzemplarz Zosinych piosnek poeta przesłał Malewskiej, od której rękopis otrzymał W. Mickiewicz, zapewne podczas przyjazdu do Wilna w 1862 roku, i umieścił w zbiorach Muzeum Adama Mickiewicza w Paryżu; zawiera 34 numerowanych piosnek, replika ofiarowana Maryli mieści 36 tekstów. 
jej największej pasji, zbierając pieśni i przysłowia ludowe: rosyjskie, ukraińskie, polskie i białoruskie.

Nie było to łatwe zadanie, jak zauważał przed laty Michał Wiszniewski, autor pierwszego tomu dzieła Historya literatury polskiej (Kraków 1840, s. 191):

Trzeba do tego mieć rzadko razem chodzące przymioty: wysokie światło, obok skromnej mowy; polor uczonego, obok prostoty obyczajów i potrzeb [...]. Lud albowiem wiejski zamyka serce i duszę przed człowiekiem, którego za coś wyższego poczytuje od siebie; nie przypuszcza go do tajemnic swoich uczuć wymykających się w słowach i piosnkach.

Czeczot zrealizował jednak swoje plany, powstały tam bowiem jego trzy pierwsze tomiki z serii Piosnek wieśniaczych, „znad Niemna i Dźwiny”, białoruskich pieśni ludowych, które tłumaczył melodyjnym wierszem metrycznym (taką, jak zaznaczał na początku, obrał metodę) i wydawał tomikami w Wilnie w latach 1837, 1839 i 1840 w zasłużonej oficynie drukarskiej Józefa Zawadzkiego ${ }^{38}$.

W Leplu funkcjonowała pięcioklasowa szkoła, założona jeszcze przez hrabiego Adama Chreptowicza w Chołopieniczach (powiat miński), a przeniesiona tu w 1832 roku. Czeczot nawiązał bliższe stosunki towarzyskie z jej prefektem oraz z nauczycielem Janem Falewiczem, wychowankami Uniwersytetu Wileńskiego. Wkrótce zdobył ogólne uznanie, zarówno u mieszkańców Lepla, jak i wśród okolicznej szlachty i włościan białoruskich, a tutejsze piosnki zaczęto nawet dlań zbierać po obywatelskich domach. Zwłaszcza panie i panienki stały się gorliwymi współpracowniczkami; im też złożył podziękowanie w przedmowie do tomu trzeciego.

W zarządzie Kanału Berezyńskiego Czeczot początkowo pełnił funkcję kolegialnego rejestratora, ale już w 1834 roku otrzymał nominację na sekretarza, a w 1838 roku kolejny awans i wyróżnienie. Niestety stan zdrowia stale się pogarszał, jedynym więc marzeniem zesłańca pozostawał powrót w rodzinne strony. W tej sprawie postanowił zwrócić się do hrabiego Adama Chreptowicza. Oficjalne zezwolenie na powrót do kraju otrzymał dopiero w 1841 roku, prawie dwie dekady po wileńskim procesie.

${ }^{38}$ Kolejno ukazały się: [1.] Piosnki wieśniacze z nad Niemna: we dwóch częściach, Wilno: druk. J. Zawadzki, 1837 (111 s.; wyd. anonim.; wstęp ,,pisano r. 1834”; dalej 50 i w cz. 2 kolejne 50 piosnek; cenzorem był L. Borowski); egz. archiwalny IBL PAN, znajdujący się w zbiorach BN (sygn.: II 792.737 A) z ded.: „Pawłowi Bärenfeldowi Jan Czeczot, r. 1839 w Leplu”; [2.] Piosnki wieśniacze z nad Niemna i Dźwiny, Wilno: druk. J. Zawadzki, 1839 (124 s.; wyd. anonim.; łącznie 120 piosnek); rec. „Tygodnik Petersburski” 1838, nr 41 i 44; inf. „Tygodnik Literacki” (Poznań) 1838, nr 9 („Jest to przekład pieśni gminnych, śpiewany przez lud litewski w białoruskiem narzeczu, po mistrzowsku dokonany”); „Kronika Emigracji Polskiej” (Paryż) 7, 1838; „Rozmaitości" (Lwów) 1839, nr 46; [3.] Piosnki wieśniacze znad Dźwiny: ksiązeczka trzecia, Wilno: druk. J. Zawadzki, 1840 (94 s.; wyd. anonim.; 100 piosnek; ded. drukiem: „Ukochanym kmiotkom znad Niemna i Dźwiny”); inf. „Przyjaciel Ludu” (Leszno) 1841, nr 27 („Trzy książeczki, z których każda nabywa się osobno. Cena każdej książeczki złp. 4"). 


\section{Na rodzinnej ziemi}

O powrocie Jana Czeczota na Litwę nie dochowały się niemal żadne informacje, chodzi zwłaszcza o rok 1840 i 1841, gdy trzej, najsurowiej ukarani w procesie filaretów, Zan, Czeczot oraz Suzin, uzyskali amnestię i urzędowe poświadczenia zakończenia wygnania. Nie wiadomo zatem nic o pierwszych dniach pobytu Czeczota na tak wytęsknionej Nowogródczyźnie, spotkaniu z matką (ojciec Tadeusz już nie żył), siostrą Teklą czy młodszym bratem Piotrem; wreszcie o jego odwiedzinach w domu Malewskich czy Puttkamerów. A trafił przecież do zupełnie innego już świata: Wilno, „Ateny Północy”, Uniwersytet Wileński, klimat i otoczenie miasta, zwłaszcza po roku 1831, roku marzeń, oczekiwań i klęski, też były już inne ${ }^{39}$.

Jedynie pełen goryczy późniejszy wiersz Powołanie poety (Pieśni ziemianina, Wilno 1846, s. 14) może wskazywać na bolesny przełom w jego życiu. Zniknął w nim bowiem romantyczny kochanek, a jego miejsce zajął rozmiłowany w ludowych pieśniach społecznik i folklorysta:

Jest czego rzewnie płakać, nie płacz sam nad sobą:

Łzami żadnej za żonę nie weźmiesz dziewicy.

Nieśmiertelna się piękność unosi nad tobą,

Tę opiewaj, pracując śród Pańskiej winnicy.

Życie Jana Czeczota po powrocie na ziemię nowogródzką było zatem pracowite, egzystencjalnie nadal trudne (już bez stałej pensji) i pełne wewnętrznej rezygnacji.

\subsection{Szczorse, Bartniki, Dołmatowszczyzna i Wolna}

Tuż po przybyciu na Litwę, w 1840 roku, Czeczot znalazł gościnę w charakterze bibliotekarza w Szczorsach u hrabiego Adama Chreptowicza (1768-1844),

39 Jakże inaczej przedstawiał się powrót Zana, który wracając na Litwę w 1841 roku przez Druskienniki, witany był pieśniami jako bohater narodowy. W czasie Bożego Narodzenia 1846 roku odwiedził Bartniki i Wolną Rafała Śliźnia, u którego mieszkał Czeczot, jednak o spotkaniu w korespondencji milczy. Dnia 29 października 1846 roku w Lebiedziewie poślubił Brygidę Świętorzecką (1825-1900); niestety wśród biesiadników zabrakło Czeczota. Wydaje się jednak, że nie była to wina Zana, lecz bardziej obustronna niechęć, u Czeczota spowodowana przepracowaniem i postępującą chorobą; H. Galle, Tomasz Zan, [w:] Album biograficzne zastużonych Polaków i Polek wieku XIX, t. 1 (red. S. Askenazy et al.), Warszawa 1901, s. 268; M. Stolzman, Nigdy od ciebie miasto...: dzieje kultury wileńskiej lat międzypowstaniowych (1832-1863), Olsztyn 1987. Adam Suzin otrzymał pozwolenie na stałe zamieszkanie w Kobryniu (gubernia grodzieńska) w 1837 roku; zajmował się tam chorym ojcem. Jednak w połowie następnego roku został zatrzymany w związku z domniemanym udziałem w spisku Szymona Konarskiego (1808-1839); nie przyznając się do winy, przebywał w więzieniu w Kijowie, następnie w Wilnie. Zgodnie z wyrokiem z 1839 roku, zatwierdzonym przez Mikołaja I (1825-1855), przetransportowany został do rodzinnych Zaleszan (pow. kobryński), gdzie znalazł się pod ścisłym dozorem policyjnym. W 1841 roku powrócił do Wilna i nawiązał kontakt z Zanem, a rok później poślubił najmłodszą siostrę A.E. Odyńca Karolinę (1818-1893); zob. J. Borowczyk, Suzin Adam (1800-1879), [w:] PSB, t. 46, Warszawa 2009, s. 105-107. 
filantropa i mecenasa nauki. Zajmował się porządkowaniem, znanego mu z czasów filomackich, pokaźnego zbioru rękopisów zgromadzonych jeszcze przez Joachima Litawora, ojca hrabiego Adama.

Czytał przy tym bardzo dużo i robił liczne notatki do planowanych przez siebie prac. W ten sposób powstały Wypisy ksiażek czytanych, z wiadomościa o nich. Notatki do historii narodu polskiego. Niestety przygotowany manuskrypt nie został wyzyskany, warto więc, choćby tylko z podanego później drukiem artykułu, znać przynajmniej tytuły przeglądanych przez niego, 22 sierpnia 1840 roku, rękopiśmiennych foliałów i dawnych książek oraz co z nich, jako warte uwagi, wynotował ${ }^{40}$.

Po śmierci hrabiego Chreptowicza filomata przeniósł się w grudniu 1844 roku do majątku Bartniki, przy drodze ze Snowia do Horodyszcza, gdzie osiadł u swych dawnych przyjaciół, rodziny Śliźniów. Przebywał tam przynajmniej do końca stycznia 1846 roku. Następnie zamieszkał w pobliskiej Dołmatowszczyźnie i, skoligaconej z poprzednikami, familii Wierzbowskich; dziedzicem dóbr był wówczas szkolny kolega Czeczota i Mickiewicza z Nowogródka Antoni Gwalbert Wierzbowski (1796-1893).

Jak wspomniano, okres ten wypełniła Czeczotowi intensywna praca twórcza, zarówno w zakresie folkloru i etnografii, jak i własnej działalności literackiej. Z zapoczątkowanej w Leplu serii Piosnki wieśniacze wydał w Wilnie trzy kolejne tomiki. W czwartym (1844), realizując przyrzeczenie sprzed kilku lat, oprócz Własnych piosnek wieśniaczych (tematycznie obejmujących zagadnienia społeczne i moralne), zamieścił dwadzieścia oryginalnych pieśni białoruskich.

W piątym tomiku (1845), już bez wersji oryginalnych, zawierającym tłumaczenia na język polski, zaznaczał, że kończy „,przedsięwziętą pracę zbierania i thumaczenia piosnek wieśniaczych", wskazując na uzupełniające jego wybór zbiory: Wacława Zaleskiego, Kazimierza Władysława Wójcickiego czy Żegoty Paulego.

Tomik szósty (1846), ze zgodą cenzury wileńskiej z 27 grudnia 1845 roku, miał największą wartość folklorystyczną, albowiem większość wydanych w nim tekstów Czeczot podał w języku białoruskim i poprzedził wstępem zawierającym charakterystykę, jak określał, ,dialektu krewickiego"; łącznie zbierając 400 pieśni znad Niemna i 557 znad Dźwiny, ogółem było ich już 957. Edycja zawierała kilka ważnych aneksów: słownik wyrazów krewickich, wykaz idiomatyzmów (,własnonazwy”) oraz dwa artykuły językoznawcze i Przysłowia krewickie ${ }^{41}$.

${ }^{40} \mathrm{Z}$ podjętego obowiązku wywiązał się z właściwą sobie skrupulatnością; zob. S. Ptaszycki, Krótkie wiadomości o rękopisach biblioteki szczorsowskiej, [w:] Zziemi pagórków leśnych..., s. 299; D.C. Chodźko, Notaty J. Czeczota, „Pamiętnik Religijno-Moralny” 2, 1858; A. Pług, Dawne testamenta (Wypisy i notatki J. Czeczota), „Kłosy” 1890, nr 1282 (w artykule poprzedzającym („Kłosy” 1889, nr 1259) autor, uzupełniając tekst, dodawał: „Jest to manuskrypt oprawny, składający się ze 170 stronic in $4^{\circ}$, zapełnionych drobnym i ścisłym charakterem, a zawierający głównie wyciągi z dzieł rozmaitych, co już zapowiada sam tytuł [...]. Wypisów tych i notatek jest 175, nie wszystkie jednak odnoszą się do książek; są między niemi wiadomości o rzeczach rękopiśmiennych, znajdujących się w bibliotece Chreptowiczów w Szczorsach [...], są i luźne jego zapiski treści rozmaitej”.

${ }^{41}$ Następne tomiki: [4.] Piosnki wieśniacze z nad Niemna i Dźwiny, z dołaczeniem pierwotwornych w mowie sławiano-krewickiéj, Wilno: druk. J. Zawadzki, 1844 (137 s.; wyd. anonim.; 
Przedsięwzięciem swym zrealizował zatem, po ponad dwudziestu pięciu latach, $\mathrm{z}$ tak bezprzykładnym oddaniem (w tym czasie poważnie chorował) dawną ideę filomacką, sformułowaną w dawnej związkowej broszurce (Opis jeograficzny..., Wilno 1821). W 1846 roku, wyjątkowo płodnym w twórczości Czeczota, ukazał się też anonimowy zbiorek Pieśni ziemianina (cenzorskie imprimatur 28 lutego 1846), zawierający jego własne wiersze. Główną ich cechą są zaprezentowane, a właściwie zamanifestowane wartości dydaktyczne - społeczne i patriotyczne (pamiątki po znakomitych Polkach i sławnych mężach) — w autorskich przypisach poparte rzetelnymi informacjami historycznymi. Całość kończy krótka, programowa dla całego tomiku, modlitwa do Stwórcy:

W Twej to mocy, o mój Boże! — Kończę pieśni moje

Na chwałę, cześć Twoję!

Natomiast do działu literatury popularyzatorskiej, zainicjowanego jeszcze w Ufie przekładem Irvinga, należą jego umoralniające Powiastki dla młodych dziewcząt (Wilno 1845) z podpisaną drukiem dedykacją z 16 sierpnia 1844 roku: „Anielce, Zosi i Marylce Domejkównom, ten Exemplarz powiastek przez siebie naśladowanych, na pamiątkę i pożytek duchowny ofiaruje Jan Czeczot”. Niewielki tomik musiał spotkać się z uznaniem nie tylko młodych mieszkanek Niedźwiadki. Prawdopodobnie mógł mieć wydanie drugie, gdyż na karcie tytułowej cytowanej edycji dochował się wprowadzony jego ręką nowy tytuł: Powieści moralne dla dziewic naśladowane z francuskiego i wtasne przez Jana Czeczota. W rękopiśmiennym zbiorku ocalały też autografy innych opowiadań, tłumaczone z pisarzy francuskich; całość zamierzał dedykować pamięci Klementyny z Tańskich Hoffmanowej (1798-1845) ${ }^{42}$.

ded.: „Dobroczynnym Panom i Rządcom ich majętności”; wstęp i Piosnki: 1-94); [5.] Piosnki wieśniacze z nad Niemna, Dniepra i Dniestra, Wilno: druk. J. Zawadzki, 1845 (108 s.; wyd. anonim.; ded.: „Zacnym i Bogobojnym Panienkom i Paniczom” i 94 Piosnek); [6.] Piosnki wieśniacze z nad Niemna i Dźwiny, niektóre przysłowia i idiotyzmy, w mowie sławiano-krewickiej, s postrzeżeniami nad niq uczynionemi, Wilno: druk. J. Zawadzki, 1846 (134 s.; nazwa aut. pod przedm.: „Pisałem r. 1845. Kwietnia 23. w Bartnikach"; ded. wierszem dla Stanisława Staszica i 100 Piosnek); [7.] Pieśni ziemianina przez Tłómacza Piosnek Wieśniaczych z nad Niemna i Dźwiny, Wilno: druk. J. Zawadzki, 1846 (58 s.; na s. tyt. pseud.; 48 Pieśni). Zob. także W. Zaleski (Wacław z Oleska), Pieśni polskie i ruskie ludu Galicyjskiego [...], Lwów 1833 (s. 516; cz. 2. Nuty); K.W. Wójcicki, Pieśni ludu Biało-Chrobatów, Mazurów i Rusi znad Bugu z dołączeniem odpowiednich pieśni ruskich, serbskich, czeskich i stowiańskich, t. 1-2, Warszawa 1836-1837 (s. 343 i 383); Ż. Pauli, Pieśni ludu polskiego w Galicyi, Lwów 1838, s. 234.

42 Powiastki dla młodych dziewcząt naśladowane z dzieła Pani de Sęt [...] przez Jana Cz...ta, t. 1-2, Wilno: druk. J. Zawadzki, 1845 (89 s.; 50 kop.; „25 września 1844 r.”); Alexis Eymery (17741854; pseud.: M.A.E. de Saintes), Delassemens [Delassement] de Mon Fils, t. 1-2, Paryż 1830 (wyd. 1). Manuskrypt (S. Świrko, Z Mickiewiczem..., s. 312 w przyp. 1), który winien być przechowywany w Wilnie („Akta Centralnego Archiwum Republiki Litewskiej nr 4/68”), najprawdopodobniej znalazł się jako Powieści moralne dla dziewic na II Aukcji Sztuki i Przedmiotów Kolekcjonerskich (poz. 108), przeprowadzonej 21 września 2017 roku; zob. „ARS-VIA” (katalogas meno ir kolekciniu vertybių aukcionas 2017 m. rugsėjo 21 d.), Wilno 2017, s. 74-75. Dedykacja: Zofia Domeyko (Domejko), około 1830 roku (żona Adama Wierzbowskiego), Aniela, Maria (żona Wilhelma, brata A. Wierzbowskiego), rodzice: Adam Domeyko (brat filomaty Ignacego) i Józefa Śliźniówna (póź- 
Kolejny manuskrypt Czeczota ma charakter religijny — to wierszowany przekład dzieła Tomasza à Kempis $O$ naśladowaniu Chrystusa. Rękopis, nad którym poeta najintensywniej pracował w Szczorsach, składa się z krótkiego wstępu i trzech ksiąg podzielonych na rozdziały. Po wstępie do całości, zatytułowanej Poezja religijna z ksiag Tomasza à Kempis, autor umieścił informację: „Tłumaczyłem r. 1840"; najwyraźniej nosił się z zamiarem druku, gdyż w tym celu w 1845 roku złożył swój tekst władzom duchownym diecezji wileńskiej ${ }^{43}$.

W ocalałych rękopisach znalazły się również, w trzech nieznacznie różniących się egzemplarzach (wersjach), Piosnki litewskie Jana Czeczota. Najpełniejszym jest ostatni, noszący podtytuł Piosnki litewskie, trzeci duplikat N 1 z objaśnien, z dodatkiem pieśni o Mingajle, Borysie, Skirmuncie, Trojnacie Mendogu, Wojsiełku, Dawidzie, Ryngoldzie i Jezbucie. Manuskrypt zbiera łącznie pięćdziesiąt pięć pieśni oznaczonych cyframi rzymskimi, niektóre w nowej redakcji, oraz zawiera dedykację bez daty i podpisu autora: „Maryi z uszanowaniem na pamiątkę poświęcam", być może wpisaną wiosną 1823 roku; za nią widnieje tytuł wewnętrzny Śpiewki o dawnych Litwinach do r. 1434.

Czeczot do osnowy faktograficznej Piosnek czerpał informacje z Kroniki Macieja Stryjkowskiego, chronologię zestawiając z Dziejami starożytnymi narodu litewskiego Teodora M. Narbutta, prezentując w efekcie swoich literackich działań oryginalną fabułę, zarówno w zakresie historycznego tematu (i dydaktycznej poetyki), jak i w przyjętej metryce, o charakterze ludowej ballady. Jak pisał we wstępie: „Czytając kronikę litewską Stryjkowskiego, trudno się wstrzymać, aby za nim nie śpiewać, tak jest poetyczna i do tego wierszem często przeplatana. Czytałem i śpiewać musiałem".

Prozaiczny wstęp do całości pracy ma jednak charakter brulionowego szkicu, zatem nie był to czystopis przeznaczony dla wydawcy. Realizację takiego patriotycznego celu mógł zapewnić jedynie druk Pieśni litewskich, lecz w ówczesnej sytuacji na Litwie nie było to możliwe ${ }^{44}$.

niejsza Antoniowa Wierzbicka), siostra Rafała i Ottona; zob. L. Kowkiel, Księgozbiór Ignacego Domeyki (w świetle inwentarza rękopiśmiennego z 1834 roku), [w:] Od strony Kresów: studia i szkice, cz. 2, red. H. Bursztyńska, Kraków 2000, s. 123-135.

${ }^{43}$ Poezja religijna zawierająca niektóre rozdziały i modlitwy z ksiag Tomasza à Kempis o naśladowaniu Chrystusa wierszem przełożone. Biblioteka Litewskiej Akademii Nauk, oddział 9-408 (cyt. za: S. Świrko, Z Mickiewiczem..., s. 312 w przyp. 1). Edycje w języku polskim na początku XIX wieku: Tomasza à Kempis, O naśladowaniu Chrystusa, ksiąg IV, przekładania T. Matuszewic[z] a roku 1818, Warszawa: druk. N. Glücksberga, 1820 (ibidem, 1824; 523 s.; Estreicher wyd. nie notuje, podobnie: Wilno 1831); zob. też Na zesłaniu..., s. 80-81 (T. Łoziński do Pietraszkiewicza, Petersburg, 18 marca 1825; pośród lektur mowa o przesłanej adresatowi edycji francuskiej). Egzemplarz otrzymany od Maryli (Warszawa 1820), zapewne w więzieniu, Mickiewicz podaruje na drogę zesłania Zanowi; dziś książeczka znajduje się w Muzeum Mickiewiczowskim w Paryżu; zob. Kronika życia i twórczości Mickiewicza..., s. 476.

${ }^{44}$ Wszystkie trzy egzemplarze znajdują się w BUWil. (S. Świrko, Z Mickiewiczem..., s. 313 w przyp. 1); M. Stryjkowski, Kronika polska, litewska, żmudzka i wszystkiej Rusi [...], Królewiec: druk. G. Osterberger, 1582 (folio, 791 s.); T.M. Narbutt, Dzieje starożytne narodu litewskiego, t. 1-9, Wilno: druk. A. Marcinowski, 1835-1841; L.A. Jucewicz, Litwa pod względem starożytnych zabyt- 
Wracając do tekstów drukowanych, w 1845 roku w setnym numerze „Tygodnika Petersburskiego" ukazała się, bezimiennie i z licznymi błędami, ostra, przedstawiająca klasycystyczne stanowisko autora, recenzja o eposie Józefa I. Kraszewskiego (1812-1887) Anafielas. Witoldowe boje. Urażony Czeczot wydał ją własnym nakładem, pod pełnym tytułem, jeden z egzemplarzy przekazując do biblioteki, osiadłych w pałacu Połoneczce (pow. nowogródzki), Radziwiłłów ${ }^{45}$.

Zajęty pracami ludoznawczymi Czeczot nie zerwał więzi z drobną poezją liryczną; przykładem jest czasopismo „Rubon” (starożytna nazwa Dźwiny), wydawane w Wilnie przez Kazimierza Bujnickiego. Kolejny rocznik (1845) drukował jedenaście Piosnek Jana Cz....tta, były to znane liryki z zesłania oraz jego późniejsze piosnki. Pośród nich znalazła się, tak popularna do dziś, Przaśnicz$k a$, która wiąże się z kolei ze Śpiewnikiem domowym cenionego już powszechnie kompozytora Stanisława Moniuszki (1819-1872) i trudami edycji jego pięciu zeszytów (litografii partytur i cenzury autorów) ${ }^{46}$.

Jesienią 1846 roku, pomimo pogarszającego się stanu zdrowia, Czeczot przeniósł się z Dołmatowszczyzny Wierzbowskich do Wolnej (powiat nowogródzki) Rafała Śliźnia (1803-1881), rzeźbiarza i mecenasa sztuk. Jednakże mimo przyjaźni gospodarza jego stosunki z domownikami nie układały się poprawnie. Wiersze, które dochowały się w tak zwanym Raptularzu Czeczota, wskazują, że

ków, obyczajów i zwyczajów skreślona przez Ludwika z Pokiewia, Wilno: druk. M. Romma, 1846 (381 s.; tu w przekł. z litewskiego przez J. Czeczota: Przeobrażenia mitologii litewskiej; Zwierzęta, ptaki, drzewa i zioła znakomitsze [...]; Ubiory i Uroczystości wiejskie; Obrzędy); T. Friedelówna [rec.] R. Koženiauskienè, ,, Giesmelēs apie senovēs Lietuvius iki 1434 metų” J. Czeczota (,Śpiewki o dawnych Litwinach do roku 1434”, Vilnius 1994), „Przegląd Artystyczno-Literacki” 2000, nr 4. Należy jeszcze wspomnieć o przypisywanej Czeczotowi powieści Żmudź i Litwa w karykaturze. Powieść z roku 1829, której rozdział piąty, Memel, przedstawiony został później drukiem; jego autorstwo wydaje się jednak wątpliwe; [I. Baliński], Urywek z nieznanej satyrycznej powieści J. Czeczota, [w:] Księga pamiątkowa..., s. 45-52.

${ }^{45}$ Niektóre uwagi, szczególniej pod względem stylu, nad pieśnia trzecia „,Anafielas. Witoldowe boje" przez p. Kraszewskiego w r. 1845 w Wilnie u Zawadzkiego wydana (Wilno: druk. M. Zymelowicza, 1846; 30 s.; „Wilno 28 Lutego 1846 r.”); zob. T. Budrewicz, Kraszewski - przy biurku i wśród ludzi, Kraków 2004, s. 87. Egzemplarz w zbiorach BN (sygn. II 74.041) zawiera dedykację: „Do Biblioteki Połoneckiej ofiaruje Jan Czeczot”. Połoneczka: jeden z majątków i pałac księcia Macieja Radziwiłła, w którym znajdowała się cenna biblioteka i archiwum; dobra odziedziczył syn Konstanty Mikołaj (1793-1869), znany jako Maciej (E. Felińska, Pamiętniki..., t. 1, Wilno 1856, s. 330-335).

${ }^{46}$ Utwory i przekłady ogłoszone za życia, chronologicznie: „Znicz” 1834 (Wilno); „Rozmaitości” (dod. do „Gazety Lwowskiej”) 1838, nr 44; „Młoda Polska” (Paryż) 1840 w Dodatku do nr 32; „Rubon” (Wilno) 1845; w t. 5: I. Zosiu! Zosiu moja miła!; II. Ona daleko; III. Rocznica; IV. Przą́niczka; V. Odprawa; VI. Młocarze; t. 6: VII. Rozkosz; VIII. Modlitwa; IX. Klatka; X. Błogosławiona, z włoskiego; XI. Najmilsza piosenka; „Ondyna Druskienickich Źródeł” (Grodno) 1846 z. 2 i 5. Zob. także S. Moniuszko, Śpiewnik domowy... [1-5], Wilno (1843-1858); zob. K. Mazur, Pierwodruki Stanisława Moniuszki, Warszawa 1970, passim. Wymagające wielu wszechstronnych studiów, zwłaszcza muzykologicznych, zagadnienie oddziaływania dorobku Czeczota na literaturę w kraju w drugiej połowie XIX i na początku XX wieku miał omówić Stanisław Świrko (Z Mickiewiczem pod rękę..., s. 312 w przyp. 5) w pracy Wybór dziet Jana Czeczota. Niestety, zamierzenia tego nie zdążył już zrealizować. 
w Wolnej (może już wcześniej w Bartnikach) doszło do sprzeczek poety z synem Rafała Mieczysławem (1834-1910), a ich podłożem mógł stać się typowy, także dla tego pokolenia, antagonizm młodych i starych.

W celu poratowania zdrowia lekarze zalecili Czeczotowi kąpiele w Druskiennikach, dokąd wyjechał wiosną 1847 roku. Kuracja nie przyniosła jednak poprawy i chory zmarł 11 sierpnia tegoż roku. Obecny przy jego łożu Józef I. Kraszewski uczcił zgon swojego niedawnego recenzenta wierszem Na śmierć Jana Czeczota, a rok później, w broszurce o Druskiennikach, dał opis jego przykładnego i niełatwego życia.

Uzdrowisko nie miało własnej parafii, poetę pochowano zatem na cmentarzu w sąsiedniej wsi Rotnica. Akt zgonu w księgach miejscowego kościoła brzmiał: „Roku Pańskiego tysiąc osiemset czterdziestego siódmego. Sierpnia jedenastego dnia, w mieście Druskienikach umarł Dworzanin Jan Czeczot, z paraliżu, SS. Sakramentami opatrzony". Dziesięć lat później Leopold Walicki, obywatel ziemi grodzieńskiej, wystawił tam granitowy pomnik, na którym wyryto epitafium Edwarda A. Odyńca ${ }^{47}$.

\subsection{Sylwetka Czeczota w ocalałej korespondencji}

Przebieg przedstawionych wydarzeń można w wielu miejscach uściślić na podstawie zachowanych listów. Tym razem jest ich wyjątkowo niewiele, w zbiorze Listów z zesłania opublikowano zaledwie sześć, z czego pięć zachowało się jedynie w późniejszych odpisach; pozostawił ich z pewnością znacznie więcej i być może przynajmniej część z niej spoczywa nadal w podworskich archiwach ${ }^{48}$.

Korespondencyjną kolekcję otwiera, opublikowany w 1948 roku, zespół pięciu listów do hrabiego Konstantego Tyszkiewicza (1806-1868) z Łohojska (pow. miński), trzy z nich poeta przesłał z Bartnik (jeden w 1844, pozostałe w 1845), dwa ostatnie datował w Dołmatowszczyźnie w 1846 roku. Z Bartnik zachował

${ }^{47}$ Ksiega pamiatkowa..., t. 1, s. 344. Druskieniki: szkic literacko-lekarski, przez J.I. Kraszewskiego i K. Wolfganga, Wilno: (druk. J. Zawadzki), 1848. Artysta malarz Rafał Wilczyński 27 lipca wykonał pożegnalny wizerunek (akwarelę); zob. Z. Gloger, Jan Czeczot, [w:] Album biograficzne zastużonych..., t. 1, s. 238; A.E. Odyniec, Na pomniku grobowym Jana Czeczota w Rotnicy, [w:] Księga pamiatkowa..., t. 1, s. 353; W. Michnia, Jan Czeczot mąż cnotliwy i przyjaciel ludu [...], „Dzwonek” (Lwów) 19, 1868, nr 15.

48 Wykaz ten w przypadku epistolografii Jana Czeczota można było wzbogacić już wcześniej, albowiem S. Świrko w 1975 roku w recenzji (Korespondencji filomatów ciąg dalszy, s. 58) zaznaczał: „Piszący powyższe słowa ma [...] w swoich zbiorach kilkanaście listów filomackich i chętnie opublikowałby je w jednym z tomów Archiwum". W 1989 roku w cytowanej rozprawie Z Mickiewiczem pod rękę [...] przytacza we fragmentach dwa z nich: J. Czeczot do A. Wierzbowskiego z Lepla 21 września 1839 (s. 243) oraz P. Czeczot, List z Niemanicy z 27 listopada 1847 (s. 292); zob. też ogłoszone drukiem: J. Czeczot, List do nieznanego adresata z Bartnik 26 grudnia 1845 r. (ibidem, s. 290; za: J. Prusinowski, Jan Czeczot, „Tygodnik Ilustrowany” 1860, nr 2); informację o kolejnym (fragmentarycznym) liście poety, pisanym ze Szczors w 1841 roku do „Kochanego Pana Piotra”, podaje też Z. Gloger (Album biograficzne..., t. 1, s. 238); żaden z nich nie uzupełnił jednak Listów z zestania Z. Sudolskiego. 
się też jeden, pisany już ręką Czeczota, list do Antoniego E. Odyńca z 1846 roku. Niestety, brakuje przesyłek z tegoż okresu skierowanych bezpośrednio do poety, bardzo istotne natomiast i tym razem (jedyne ślady filomackich rozmów) pozostają dość liczne wzmianki o nim w korespondencyjnym kręgu przyjaciół oraz osób mniej lub bardziej mu bliskich ${ }^{49}$.

Hrabia Konstanty Tyszkiewicz, gdy ukończył Uniwersytet Wileński (nauki prawne), po krótkich rozjazdach powrócił do swych dóbr na Litwie, już nie tylko jako posiadacz ogromnej wiedzy historycznej, geograficznej, literackiej, lecz także jako gorliwy krzewiciel idei społecznych. Od początku pobytu w swoich rodzinnych dobrach w Łohojsku dążył do podniesienia dobrobytu mieszkańców, czym z pewnością, oprócz wspólnego z Czeczotem umiłowania książek (miał zasobną bibliotekę), wzbudził szacunek byłego zesłańca; stąd tak ciepły (i cierpki czasem) ton listów i odpowiednio stonowana w postawie nadawcy poufałość wobec magnata. W liście z 28 grudnia 1844 roku pisał:

Jeszczem nie złożył Jaśnie Wielmożnemu Panu winnego podziękowania za dobry i za drogi nawet, jak dla mnie, tytuń, który dotąd palę przypominając często dobroć i łaskę, prawdziwie wspaniałą, Pańską. Składając więc teraz najszczersze moje podziękowanie za tak hojny podarunek, ośmielam się ofiarować Obojgu Jaśnie Wielmożnym Państwu Dobrodziejom egzemplarz czwartej książeczki [Wilno 1844] piosnek moich wieśniaczych [...]. Ponieważ jednak — zaznaczał dalej — dosyć już przez pięć lat jadłem łaskawego chleba, życzyłbym sobie [w Łohojsku] jakkolwiek mieć zapracowany i być prawdziwym sługą. Jeśli więc takiego J. W. Hrabia potrzebować będzie, może kiedy wezwać mię do swej Biblioteki i Archiwum: bo do innego obowiązku zdaje się, że nie zdolny już jestem.

Kolejne dwa listy, podobnie jak dwa ostatnie z Dołmatowszczyzny, dają krótkie opisy niemal pół setki rzadkich druków, które Czeczot oferuje hrabiemu do nabycia, w charakterystyczny dla siebie sposób też nadmieniając: ,Takie właśnie kaleki stare i obdartusy są ozdobą bibliotek, co są i pałacami dla dzieł nowych i szpitalami przedłużającemi życie starych książek".

W drugim z nich pisze już wprost, wykładając swoje filomackie poglądy i społeczne credo:

Lubo JWPan zrobiłeś mi zarzut względem rozpieszczenia Ekonomowien klasycznemi piosnkami, trwam jednak w mojem przedsięwzięciu wydania dla nich kilkogroszowych książeczek z temi piosnkami, i jużem przygotował do druku ten wybór [...]. Mnie, ekonomskiemu też dziecku — kończył swoje sercem pisane poglądy — proszę nie mieć za rzecz zdrożną, iż chciałbym ich dzikie obyczaje przynajmniej piosneczką łagodzić, a jeśli w tej intencji ujrzymy Pana Hrabiego współczucie, będziemy rokować sobie, że z czasem w naszych wadach przy pomocy Boskiej poprawić się możemy.

Niestety tak „radykalnych poglądów” hrabia Konstanty Tyszkiewicz nie raczył już przyjąć i Jan Czeczot pozostał „na łaskawym chlebie”, rezydując nadal u Wierzbowskich i Śliźniów.

49 Z. Krzyżanowska, Listy Jana Czeczota do Konstantego Tyszkiewicza (1844-1846), „Pamiętnik Literacki” 1948, s. 507-521 (toż w odb.: Studia mickiewiczowskie: w 150 rocznice urodzin poety, red. J. Krzyżanowski, Warszawa 1948); przedruk pierwodruków w Listy z zesłania, t. 2, passim; zob. też Z. Rydlewska, Konstanty Tyszkiewicz i jego kontakty z Towarzystwem Naukowym Krakowskim, „Rocznik Biblioteki Naukowej PAU i PAN” (Kraków) 2015, s. 19-27. 
Ostatni z zachowanych listów zaadresował z Bartnik 18 stycznia 1846 roku do związkowego Telemaka, jakże odmiennie niż przed laty w Wilnie czy na zesłaniu: „Szanowny Panie Edwardzie Dobrodzieju!’. Pisał tam między innymi o sprawach edycji swojej krytyki Witoldowych bojów Kraszewskiego (,200 egzemplarzy na najtańszym papierze”) oraz „niedostatku” książek gramatycznych Józefa Mrozińskiego, Wojciecha Szwejkowskiego i Józefa Królikowskiego, nadmieniając tylko (bez oczekiwania odpowiedzi), że sam pisze „tak, jak się wymawia”50.

W sprawie lektur dodawał jeszcze:

Pracuję jak mogę i ile zdrowie pozwala, książki lepsze nowo wychodzące, rzadko widuję. Czytam za to sobie Argenidę [dzieło było też w bibliotece Chreptowiczów] dziwaczną, staroświecką, a nawet teatr starodawny Radziwiłłowej, jeśli cierpliwości dostanie, a czego lepszego czytać nie będzie. Taka to wiejska literatura, za to spi się dosyć, nudzi się trochę, ale żyje spokojnie, nie tak jak w miastowym gwarze ${ }^{51}$.

Sporo informacji uzupełniających sylwetkę Jana Czeczota wnoszą listy przyjaciół i osób mu najbliższych, przykładem jest korespondencja Zana do Franciszka i Heleny Malewskich, gdy z Wilna 20 października 1841 roku pisał:

Pierwszego października na koniec przybyłem do Szczors, nie znalazłem wtedy samego hrabiego, tym więcej mogłem oddać czas Janowi. Gdyby kto z boku patrzał na nas, miałby widok Płaksy i Wesołowskiego; komedyę tę widziałem w Wilnie, pierwszą w języku ojczystym po dwudziestu latach [...]. Czeczot tak się wyćwiczył z każdego przedmiotu i osoby wyciągnąć sobie boleść i uczynić nieumyślną przykrość, jak ja ulgę i rozrywkę. Zabiera się, jak się zdaje, do opuszczenia tego miejsca, nie wprzód jednak, aż katalog biblioteki szczorsowskiej ułoży ${ }^{52}$.

${ }^{50}$ J. Mroziński, Zasady (Pierwsze) Gramatyki języka polskiego [...], Warszawa: druk. N. Glücksberga, 1822 (97 s.); oraz Odpowiedź na umieszczona w „, Gazecie Literackiej” recenzye dzieła pod tyt. Pierwsze zasady Gramatyki języka polskiego, Warszawa: druk. N. Glücksberga, 1824 (300 s.); W.A. Szwejkowski (Szweykowski), jeden z najbardziej znanych działaczy oświatowych okresu Królestwa Polskiego, autor rozpraw Uwagi nad wyższemi Szkołami polskiemi, w porównaniu do niemieckich..., Warszawa: druk. Pijarów, 1808 (112 s.); i O znakach pisarskich nad samogłoskami, „Programma Liceum Warszawskiego na r. 1816” (osobno: O znamionach pisarskich nad samogłoskami, Warszawa 1816); J.F. Królikowski, prawnik i historyk literatury, autor między innymi: Rozprawa o śpiewach polskich z muzyka [...], „Pamiętnik Warszawski” 9-10, 1817-1818 (wyd. zm. Rozrywki literackie proza i wierszem, t. 1-2, Poznań 1824); Prozodia polska, czyli o śpiewności i miarach języka polskiego [...], Poznań 1821 (215 s.) i „Mrówka Poznańska” 1, 1821; tu: Wstęp (o zepsuciu języka polskiego w Wielkopolsce i germanizmach).

${ }^{51}$ Jan Barclai (Barklay; 1582-1621), autor alegorycznej powieści, w przeróbce W. Potockiego (1621-1696), Argenida [...], Warszawa: druk. Pijarów, 1697 (folio, 761 s.); także: Kraków 1704; Lipsk 1728; Poznań (1743) i Wilno 1756; zob. [rec.] B. Gubrynowicz, ,Argenida” Wactawa Potockiego w stosunku do swego oryginatu, W. Bobek, Kraków 1929, „Pamiętnik Literacki” 1929, z. 1/4. Urszula Franciszka Radziwiłłowa (1705-1753), z książąt Wiśniowieckich, matka Karola Stanisława „Panie Kochanku”, autorka 16 utworów scenicznych (pisanych też dla teatru w Nieświeżu), drukowanych jako Komedie i tragedie... (Żółkiew 1754; 354 k.; prawdopodobnie istniało wyd.: Nieśwież 1751), w których łączyła fantastykę i groteskę z klasyczną przejrzystością stylu (znała i przekładała komedie Moliera).

${ }^{52}$ Nieśwież (gub. mińska), stolica ordynacji Radziwiłłów nad Uszą. Ludwik A. Dmuszewski, Płaksa $i$ Wesołowski, według N. Braziera i Ch.A. Sewrina, prapremiera w Warszawie w 1817 roku (idem, Dzieła dramatyczne, t. 3, Wrocław 1821). Wykorzystana korespondencja (Listy z zesłania, 
Dwa lata później, już z Dołmatowszczyzny, dodawał:

Czeczot opuścił Szczorsy i mieszka tutaj, ma się za cierpiącego i nie znosi mnie jako żywego przeczenia jego zasad życia i bycia. Z jednych i tychże samych przedmiotów bierzemy powód, on do ubolewania i skarg i zrzędzeń, ja do pokrzepiania się, dziękczynień i pochwał. Wydaje czwarty tomik pieśni, który jest w połowie w języku mużyckim [ros. mużik — wieśniak]. Żaden z następnych nie dorównywa, mojem zdaniem, pierwszemu, który jest najlepszy. Przez wzgląd, jak myślę tajemny, na poetyczne swoje zajęcia okazuje wstręt do wszelkiej służby lub obowiązku; przecież mam nadzieję, że musi pójść na archiwistę do Nieświża, dokąd jest wzywany.

Pamiątki po „cierpiącym” Czeczocie przechowywał jednak do końca swoich dni, albowiem jeszcze w listopadzie 1852 roku informował Malewskich: „Po dożynkach w Berezowce sprawionych na cześć sp. spiewaka Pieśni Wieśniaczych, już w październiku ruszyliśmy na zimowe leże do Kochaczyna, wszyscy pięcioro dzięki Bogu zdrowi i szczęśliwi jak tylko można na tym padole płaczu”.

\subsection{Czombrów, panny Karpowiczówne i wrocławski tomik}

Niewielki dworek w Czombrowie (w zapisach także Cząbrów, około 18 km na południe od Nowogródka) był doskonale znany Mickiewiczowi i zapewne też Czeczotowi jeszcze $\mathrm{z}$ lat chłopięcych. W badaniach historycznoliterackich, a przede wszystkim w świadomości społecznej, mimo rywalizacji innych nie mniej magicznych zakątków ziemi nowogródzkiej (w 1928 roku filmowano tam Pana Tadeusza), miejsce to i sam dworek na trwałe połączyć się jednak miały z poetyckim (i geograficznym) obrazem Mickiewiczowskiego Soplicowa ${ }^{53}$.

Swoimi dziejami Czombrów sięga 1685 roku, gdy kolejny właściciel okolicznych dóbr (Miratycze, Pieszczanka, Świteź) Stefan Kurcz, wojewoda brzeski, ufundował w pobliskiej Walówce kościół z klasztorem ojców dominikanów. W 1794 roku Czombrów nabył od Eleuterego Siemiradzkiego sędzia nowogródz-

t. 2, passim), chronologicznie: [1.] T. Zan do F. i H. Malewskich. Wilno, 20 października $1841-$ s. 178; [2.] Dołmatowszczyzna, listopad 1842 - s. 195; [3.] Dołmatowszczyzna, [7 lutego] 1843 — s. 197; [4.] Lepel, 31 maja 1844 - 203; [5.] [Kochaczyn, 8 listopada 1852 - s. 242. Warto też zwrócić uwagę na list Malewskiego do Mickiewicza. Karlsruhe, 18 października 1843 (Listy z zestania, t. 3, s. 365) — „O Janku dawno nic nie wiemy. Gościł on długo w Szczorsach, a teraz podjął obowiązki w dobrach Witgenszteina (poradziwiłłowskich). Wydał nowy poszyt pieśni; widział go Tomasz, ale się z sobą nie zrozumieli".

53 Jeszcze w haśle redakcyjnym Soplicowo (Stownik geograficzny Królestwa Polskiego i innych krajów stowiańskich [= SGKPiL], red. F. Sulimierski, B. Chlebowski, W. Walewski, t. 1-15, Warszawa 1880-1914, t. 11, Warszawa 1890, s. 76) przeczytać można, że to okolica szlachecka upamiętniona w Panu Tadeuszu; zob. też Walówka, SGKPiL, t. 12, Warszawa 1892, s. 916; Chryzostom Ładzic [Al. Walicki], Aniela z Wierzejskich Uzłowska, matka chrzestna Mickiewicza, „Pamiętnik Towarzystwa Literackiego im. Adama Mickiewicza" (Lwów) 1889, s. 265-266; L. Podhorski-Okołów, Zajazd czombrowski w świetle dokumentów, „Ruch Literacki” 1934, $\mathrm{nr} 2$; [w:] idem, Realia Mickiewiczowskie, s. 404-418; D. Pluta, Z wokandy sądów nowogródzkich. Kilka szczegótów z działalności prawniczej Mikołaja Mickiewicza, [w:] Od oświecenia ku romantyzmowi...: autorzy — dzieła — czytelnicy, cz. 5, red. M. Piechota, Katowice 2014, s. 54-80. Karolina Wojnarowska, autorka książek o treści wychowawczej, Pierścionki Babuni, czyli bieg życia kobiety w pięciu oddziatach przez autorkę „, Stów kilku do matek polskich", t. 1-4, Lipsk 1845. 
ki Józef Uzłowski (zm. ok. 1828), ożeniony z Anielą Wierzejską (zm. 1830), matką chrzestną Adama Mickiewicza.

Uzłowscy zaś zatrudniali w czombrowskim dworze na posadzie ekonoma szlachcica Mateusza Majewskiego, a jako pannę apteczkową jego córkę Barbarę. Stąd wnioskować można, że przyszły poeta odwiedzał tam chętnie i wielokrotnie dziadka Mateusza oraz swoją chrzestną matkę Anielę, dziedziczkę Czombrowa.

Związki te były zapewne podtrzymywane jeszcze po 1814 roku: wówczas to Józef Uzłowski przekazał swoje dobra synowi Kazimierzowi, a gdy w 1832 roku zadłużony majątek kupił ich daleki krewny Kazimierz Karpowicz (ok. 1792 1865), palestrant nowogródzki, okazało się, że to dawny kolega Adama i Jana z nowogródzkiej szkoły.

Dla pełności obrazu związków towarzyskich i rodzinnych dodać jeszcze pozostaje, że Kazimierz Karpowicz przed nabyciem Czombrowa pojął za małżonkę pannę Benedyktę Haciską (1800-1858), najpewniej spokrewnioną z Czeczotem przez matkę Klarę, i niebawem rytm życia tutejszego dworku, ,pośród pagórków leśnych i łąk zielonych”, wypełnił gwar ich pięciorga dzieci, synów Albina (1826), Kazimierza (1830), Juliana (1831) oraz córek: Alojzy (1833) i Konstancji (1837).

Gdy synowie zaczęli podrastać, Kazimierz Karpowicz (jak potwierdza rodzinna korespondencja) dla podreperowania finansów w 1838 roku wydzierżawił Czombrów, sam administrując majątkiem w Rosi koło Wołkowyska, Benedykta zaś zamieszkała w pobliskiej Świsłoczy; w tamtejszym gimnazjum nauki pobierali synowie.

Rozłąka miała trwać do maja 1846 roku: małżonka, przejmując na siebie obowiązki prowadzenia domu, gospodarstwa i edukacji córek, powróciła do czombrowskiego dworku dwa lata wcześniej. Starsza Konstancja zajmowała się ogrodem, a jedną z ulubionych lektur dziewczynek stały się Pierścionki babuni Karoliny Wojnarowskiej.

Z późniejszego opisu Romana Aftanazego wynika, że zewnętrzne ściany dworu były bielone, wnętrze

mieściło dziesięć pokoi w układzie dwutraktowym z korytarzem i schodami wiodącymi na piętro, w lewym skrzydle. Przed domem ciągnął się rozległy kolisty trawnik, obsadzany krzewami. Rosły na nim również strzeliste topole włoskie [...]. Od tyłu domu znajdował się ogród kwiatowy i owocowy.

Tym właśnie pannom na Czombrowie — „Kochanym Siostrzenicom Aloizce i Kostuni" - w 1846 roku ofiarował Jan Czeczot z odręczną dedykacją szósty, świeżo wyszły spod pras drukarskich, tomik Piosnek wieśniaczych. W czombrowskim egzemplarzu wklejono, wielkością dostosowany do wymiarów tomiku, wskazany tytułem podjętej pracy, list poety do obu panien Karpowiczówien, napisany na zwykłym bibulastym papierze (bez znaków wodnych) i datowany 4 lipca 1845 r. w Bartnikach:

Kochane Siostrzeniczki! Posyłam dla Was i dla waszych braciszków exemplarz piątej xiążeczki moich piosnek wieśniaczych, przypisany ogólnie „Zacnym i bogobojnym panienkom i pani- 
czom". Życzę z duszy, abyście się w rzędzie ich ze swemi braciszkami liczyły. Drugi takiż exemplarz oddacie swojej Nauczycielce Szanownej Pannie Estelli, i oświadczycie jak jej, tak i swojej Mamusi moje uszanowanie. O odebraniu tych xiążeczek mam nadzieję, iż mię uwiadomicie i pokażecie, jak umiecie pisać.

Życzę Wam być zawsze dobremi, posłusznemi i ochoczemi do nauki i czytania xiążeczki, równie jak do gospodarstwa i robotki, zawsze przychylny i kochający was Jan Czeczot ${ }^{54}$.

List dedykacyjny do panien Karpowiczówien dotyczy zatem ofiarowanej już wcześniej edycji Piosnek wieśniaczych z 1845 roku; może również z odręcznym wpisem i dedykacją? Sam list jest natomiast interesujący przynajmniej z kilku powodów: na tle pozostałej korespondencji, zwłaszcza wysyłanej w tym czasie z Bartnik, tchnie wyraźnym optymizmem nadawcy (oczekuje reakcji i odpowiedzi) oprócz typowego nie tylko dla poety, lecz także filomatów dydaktyzmu w zakresie przynależnych do wieku prac i umiejętności jego adresatek. Optymizmem, albowiem Czeczot pisał przecież do nastoletnich siostrzenic (bliższych informacji o powinowactwie nie udało się ustalić) i swą treścią zaświadcza wymownie o jego wciąż altruistycznej postawie (dwa darmowe egzemplarze). Następnie, choć to już dalsza perspektywa, przybliża domową atmosferę Czombrowa: w 1845 roku rodzina nie była jeszcze w komplecie, a Benedykta Karpowiczowa, dbając o edukację córek, oprócz wspomnianych przez poetę ,robótek” (szycia i haftowania) zatrudniała guwernantkę z pewnością uczącą je również śpiewu i gry na fortepianie.

Wspomniany piąty tomik Piosnek wieśniaczych prawdopodobnie nie zachował się już w dworskiej bibliotece, ale szósty dotrwał tam przynajmniej do 1943 roku, albowiem dwór w Czombrowie przetrwał wszystkie najtrudniejsze narodowe dzieje: powstania XIX wieku, kataklizm Wielkiej Wojny i nawały bolszewickiej 1920 roku, ,przeżył” okupantów i apokalipsę II wojny światowej, aż nadszedł wieczór 16 maja 1943 roku, gdy dzieląc los setek, podobnych mu dworków na Nowogród-

${ }^{54}$ Egzemplarz BU we Wrocławiu (sygn. 2956 II; akc.: $1948 \mathrm{~K} \mathrm{532;18 \times 11} \mathrm{cm)} \mathrm{znalazł} \mathrm{się}$ w tutejszych zbiorach w wyniku postanowień reformy rolnej z 9 lipca 1945 roku i przejmowania przez państwo zabytkowych nieruchomości, w tym księgozbiorów podworskich. Na magazynową półkę trafił drogą zakupu w 1948 roku i, jak miało się niebawem okazać, prawdopodobnie nieznany czytelnikom (brakuje przecież jakichkolwiek informacji w literaturze przedmiotu) przeleżał tam przez blisko 50 lat. Na tomik zwróciłem uwagę (zapisując jedynie sygnaturę) podczas skontrum, w 1990 roku, zdziwiony, że mimo cennej zawartości nie znalazł się przynajmniej w dziale bibliotecznych cymeliów. Swoje odkrycie chciałem przedstawić drukiem, gdy po 2000 roku zbierałem materiały do pracy Pośród filomackich darów dla szkoły powiatowej w Kownie, w pierwszej z nich zaznaczając jedynie, że w tutejszej bibliotece znajduje się znaczna liczba publikacji z przeróżnymi znakami własnościowymi: od autografów Niemcewicza po dziewiętnastowieczne dedykacje na szkolnych podręcznikach, o których informacje wzorem ZN im. Ossolińskich można by udostępnić choćby w bibliofilskiej edycji. Wówczas okazało się, że niestety w katalogu uniwersyteckim nie ma kart identyfikacyjnych (autora i odsyłaczy), zaginionych być może tuż po opracowaniu książeczki; szczęśliwie pozostała po niemałych trudach odnaleziona sygnatura. Dziś luka ta z pewnością zostanie uzupełniona, a same Piosnki wieśniacze wraz z listem Czeczota, jako przykład ocalałego dziedzictwa narodowego, poddane ogólnie dostępnemu w internecie zapisowi cyfrowemu. 


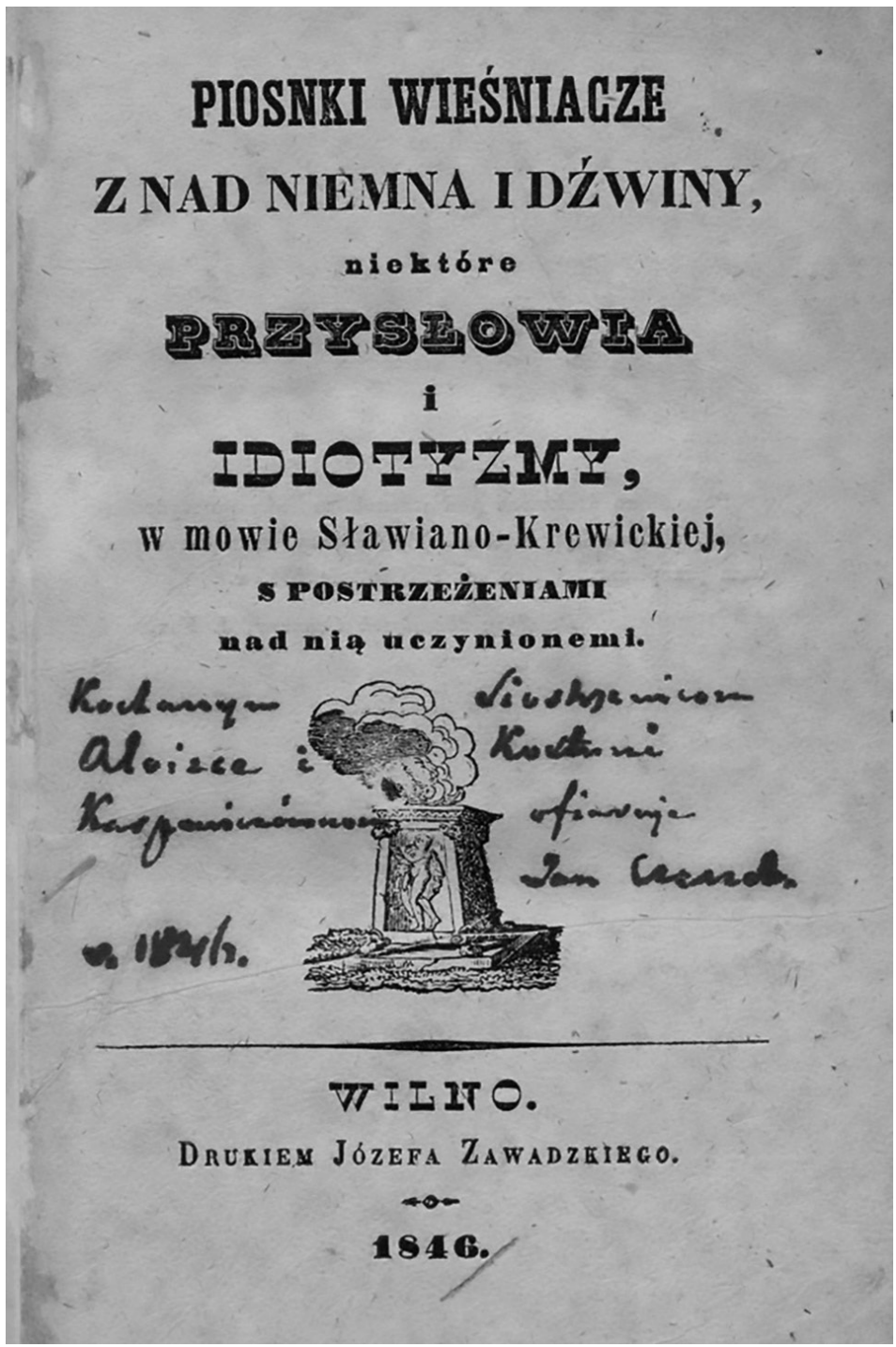

I1. 2. Dedykacja Jana Czeczota na szóstym tomiku Piosnek wieśniaczych... (Wilno 1846) dla siostrzenic „Aloizy i Kostuni Karpowiczówien”.

Egzemplarz Biblioteki Uniwersyteckiej we Wrocławiu, sygn. 2956 II. 


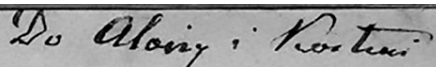

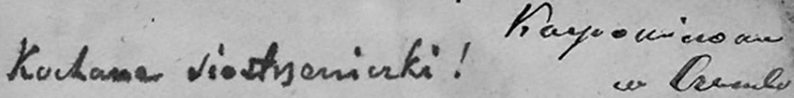

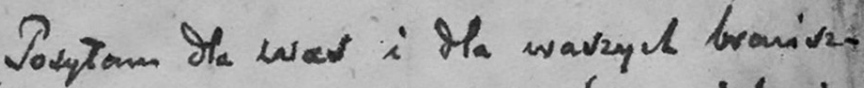
kow exemplare pigty' tiavierrki minis gio. snek wiedinaryeh, fraypisany ogölinie Zace.

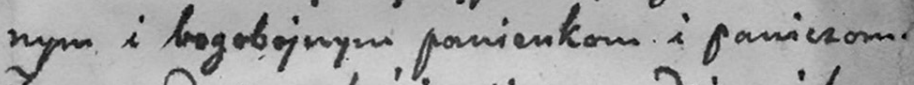
Jyere 2 Dudry, abytive clie w netzie inh te twemi hravivekami liengty. Dragi takiz

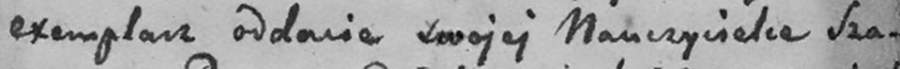

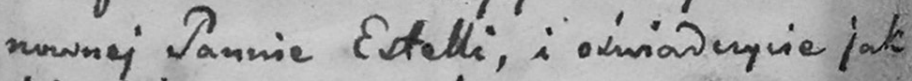
Mi, tak i vwojej Mamumi mije uvanno-

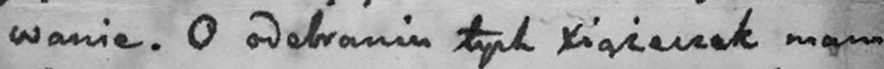

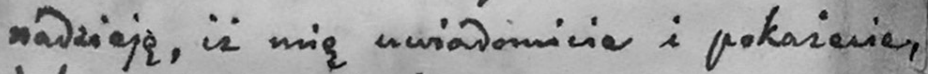
ink uniceic pivan.

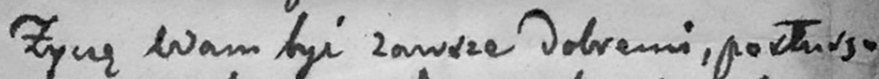
nemi i oularemi d ranki ingtania

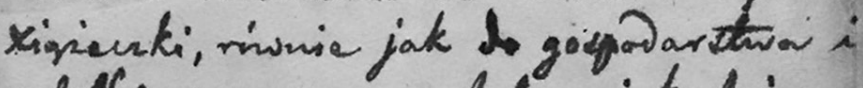

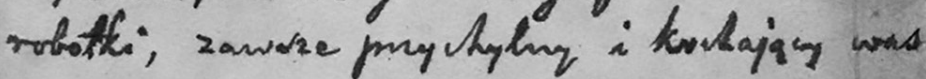
Lan Creveot.

- 1845 Lipica 4. wartivikank.

Il. 3. List Jana Czeczota z 4 lipca 1845 roku z Bartnik do Alojzy i Konstancji Karpowiczówien z Czombrowa. Egzemplarz Biblioteki Uniwersyteckiej we Wrocławiu, sygn. 2956 II. 
czyźnie (Worończy, Siohodzie, Mołodowie), za sprawą urzędujących tu sowieckich partyzantów zgorzał doszczętnie na oczach zrozpaczonych domowników ${ }^{55}$.

\section{Kilka spostrzeżeń i zakończenie}

Tak w świetle zgromadzonych materiałów biograficznych (związkowych i literackich) oraz ocalałej korespondencji przedstawia się zarys sylwetki filomaty, poety, folklorysty Jana Czeczota - jego pracowita droga życiowa, trud podejmowanych przezeń obowiązków i przyjęty na lata związkowy nakaz patriotycznych powinności.

Samouk, niespełniony student Uniwersytetu Wileńskiego, który już z rodzinnego środowiska wyniósł gruntowną znajomość folkloru, białoruskiego, polskiego i litewskiego, rozległą profesjonalną wiedzę, którą kultywować i wzbogacać będzie, podając drukiem jej dokumentarne i wielostronnie poznawcze wyniki, przez całe swoje pełne poświęceń i dość krótkie życie odsuwając na bok marzenia o własnej, pozostającej do dziś w rękopisach, twórczości poetyckiej.

W pamięci nie tylko historyków literatury pozostanie jako przyjaciel Mickiewicza, piosenkarz filomacki, ale i, co starano się tu zasygnalizować, jako zbieracz pieśni ludowych, wpisujący się w szeroki krąg osób określających się dumnie, jako gente Lithuanus, natione Polonus, lecz to już temat na inne analizy i treści.

\section{Bibliografia (w wyborze)}

\section{Materiały źródłowe i dzieła treści ogólnej}

Archiwum filomatów, cz. 1. Korespondencja 1815-1823, t. 1-5, wyd. J. Czubek, Kraków 1913; cz. 2. Materiały do historii Towarzystwa Filomatów, t. 1-3, wyd. S. Szpotański i S. Pietraszkiewiczówna, Kraków 1920-1921; 1934; cz. 3. Poezja filomatów, t. 1-2, wyd. J. Czubek, Kraków 1922. Archiwum filomatów, t. 1. Na zesłaniu, red. C. Zgorzelski, Wrocław 1973.

Archiwum filomatów: Listy z zesłania, t. 1. Krag Onufrego Pietraszkiewicza i Cypriana Daszkiewicza, zeb. Z. Sudolski, Warszawa 1997; Listy z zestania, t. 2. Krag Tomasza Zana, Jana Czeczota i Adama Suzina, zeb. Z. Sudolski, Warszawa 1999; Listy z zestania, t. 3. Krag Franciszka Malewskiego i Józefa Jeżowskiego, zeb. Z. Sudolski, Warszawa 1999; Listy z więzienia, t. 4, oprac. Z. Sudolski, Warszawa 2000.

Beauvois D., Wilno: polska stolica kulturalna zaboru rosyjskiego 1803-1832, przeł. I. Kania, Wroclaw 2010.

Bibliografia literatury polskiej „,Nowy Korbut”, t. 7. Romantyzm, oprac. I. Śliwińska, S. Stupkiewicz, Warszawa 1968, s. 246-249 (Czeczot Jan: 1796-1847).

${ }^{55}$ Dwór polski w XIX wieku: zjawisko historyczne i kulturowe, t. 1, red. J. Baranowski, Warszawa 1992; R. Aftanazy, Dzieje rezydencji na dawnych kresach Rzeczypospolitej, t. 2, Wrocław 1992, s. 194; W. Wiśniewski, Ostatni z rodu: rozmowy z Tomaszem Zanem [1902-1989], Paryż 1989; K. Węgorowska, Nostalgiczny językowy obraz międzywojennego czombrowskiego dworu utrwalony w retrospektywnych impresjach Zofii Brzozowskiej, „Annales Universitatis Paedagogicae Cracoviensis” 2013 (,Studia Linguistica” 8). 
Borowczyk J., Rekonstrukcja procesu filomatów i filaretów 1823-1824: historia śledztwa przeciw uczestnikom konspiracji studenckich i młodzieżowych w Wilnie oraz w Wileńskim Okręgu Naukowym, Poznań 2003.

Kronika życia i twórczości Mickiewicza: lata 1798-1824, red. S. Pigoń, oprac. M. Dernałowicz, K. Kostenicz, Z. Makowiecka, Warszawa 1957.

Listy do Adama Mickiewicza, oprac. M. Dernałowicz et al., red. E. Jaworska, M. Prussak, t. 1, Warszawa 2014.

Mickiewicz A., Dzieła (wyd. rocznicowe 1798-1998), t. 14. Listy, cz. 1. 1815-1829, oprac. M. Dernałowicz, E. Jaworska, M. Zielińska, Warszawa 1998.

Polski Stownik Biograficzny, red. W. Konopczyński , t. 1-, Kraków 1935-.

Stownik geograficzny Królestwa Polskiego i innych krajów słowiańskich, red. F. Sulimierski, B. Chlebowski, W. Walewski, t. 1-15, Warszawa 1880-1914.

\section{Artykuły i opracowania}

Borowczyk J., Zesłane pokolenie. Filomaci w Rosji (1824-1870), Poznań 2014.

Cwenk M., Czeczot (jeszcze) nieznany: uzupetnienie „Poezji filomatów” J. Czubka, [w:] W cieniu Mickiewicza, red. J. Lyszczyna, Katowice 2006, s. 212-223.

Dwór polski w XIX wieku: zjawisko historyczne i kulturowe, t. 1, red. J. Baranowski, Warszawa 1992.

Frączek M., Jan Czeczot - prekursor białoruskiej folklorysty, [w:] Romantycy na krańcach świata: podróże egzotyczne i peregrynacje wewnętrzne, red. E. Modzelewska, Kraków 2015, s. 133-140.

Яцкевіч 3., Радавод Яна Чачота, „Беларусіка-Albaruthenica” t. 10, Mińsk 1998, s. 5-11.

Jędrychowska B., Polscy zesłańcy na Syberii (1830-1883). Działalność pedagogiczna, oświatowa i kulturalna, Wrocław 2000.

Kleiner J., Mickiewicz, t. 1. Dzieje Gustawa, Lublin 1948 (wyd. 1 Lwów 1934).

Kowkiel L., Księgozbiór Ignacego Domeyki (w świetle inwentarza rękopiśmiennego z 1834 roku), [w:] Od strony Kresów: studia i szkice, cz. 2, red. H. Bursztyńska, Kraków 2000, s. 123-135.

Podhorski-Okołów L., Realia Mickiewiczowskie, wyd. 2, Warszawa 1999.

Puchalska J., Dziedziczki Soplicowa, Warszawa 2014.

Saloni J., Czy nieznane poezje Mickiewicza?, „Sprawozdania Polskiej Akademii Umiejętności” 49, 1948, nr 9, s. 481-484.

Saloni J., Pieśniarz i śpiewaczka. Rzecz o Janie Czeczocie i Zofii Malewskiej, „Prace Polonistyczne", seria XVI (Łódź) 1960, s. 44-86.

Saloni J., Rękopisy ze spuścizny po Zofii Malewskiej, „Pamiętnik Literacki” 38, 1948, s. 490-506.

Sudolski Z., Jan Mieczkowski sybirak-konfederata, czyli u początków romantycznej recepcji Baru, „Napis” seria V (Warszawa) 1999, s. 177-191.

Sudolski Z., Mickiewicz wśród filomatów w więzieniu i na zestaniu, [w:] Mickiewicz w Gdańsku. Rok 2005, red. J. Bachórz, B. Oleksowicz, Gdańsk 2006, s. 13-30.

Sudolski Z., Między Ufą a Warszawa (1828). Jana Czeczota piosnki i listy z zestania do Antoniego Edwarda Odyńca, [w:] idem, Tropem detektywa: studia, materiaty, sylwetki, t. 1, Warszawa 2009, s. 102-114.

Świrko S., Jan Czeczot jako redaktor i korektor drugiego tomu Poezji Mickiewicza, „Rocznik Towarzystwa Literackiego im. A. Mickiewicza" 7, 1972 (druk: 1973), s. 67-97.

Świrko S., Korespondencji filomatów ciag dalszy, „Rocznik Towarzystwa Literackiego im. A. Mickiewicza" 10, 1975, s. 57-59.

Świrko S., Nieznany kopiariusz poezji Mickiewicza, „Rocznik Towarzystwa Literackiego im. Adama Mickiewicza” 1, 1966, s. 25-60 (wersja poszerz. „Przegląd Humanistyczny” 1968, nr 4 (67), s. 115-132).

Świrko S., Twórczość więzienna Jana Czeczota i jej związki z poezją Adama Mickiewicza, „Rocznik Towarzystwa Literackiego im. A. Mickiewicza" 9, 1974, s. 25-54. 
Świrko S., Z kręgu filomackiego preromantyzmu, Warszawa 1972.

Świrko S., Z Mickiewiczem pod rękę czyli życie i twórczość Jana Czeczota, Warszawa 1989.

Witkowska A., Rówieśnicy Mickiewicza: życiorys jednego pokolenia, Warszawa 1962.

Zgorzelski C., O tzw. „Raptularzu” Czeczota, „Rocznik ZN im. Ossolińskich” 4, 1953, s. 63-76.

\section{Jan Czeczot's letters. Factual materials in the manuscripts}

Summary

The goal of this study is a presentation of a recently discovered, unknown letter of Jan Czeczot from 1845 against a biographical and historical background. According to the fact that an evaluation of the sources, mainly manuscripts and range of their use in the available biographical works is still far from a monographic level, a more complex view on the Philomath's figure must be postponed until the publication collecting the entity of the materials (Association - related, literary and epistolographical) of Filareci's trial, his exile and patriotic activity after his return. The presented, even partial study, seems to reveal that Jan Czeczot stayed true to the Philomaths Association's devotion to "national duties" and was not enshadowed by Adam Mickiewicz or Filareci's legend of his times. We ought to see him more widely: he was one of the first important folklorist poets, the author of valuable ethnographic works, confirming the exceptional persistence of Filarets' organisational bonds with his attitude.

Keywords: Jan Czeczot, Romanticism, Philomaths, biography, epistolography, poetry, translations, folk songs, folklore 